Review

\title{
The Application of Supercritical Fluid Extraction in Phenolic Compounds Isolation from Natural Plant Materials
}

\author{
Katarzyna Tyśkiewicz *(i), Marcin Konkol and Edward Rój \\ Supercritical Extraction Department, New Chemical Syntheses Institute, Al. Tysiąclecia Państwa Polskiego 13A, \\ 24-110 Puławy, Poland; marcin.konkol@ins.pulawy.pl (M.K.); edward.roj@ins.pulawy.pl (E.R.) \\ * Correspondence: katarzyna.tyskiewicz@ins.pulawy.pl
}

Received: 18 September 2018; Accepted: 8 October 2018; Published: 12 October 2018

check for updates

\begin{abstract}
The separation of phenolic compounds by supercritical fluid extraction has been widely studied throughout the last two decades. This is evidenced by a number of publications and articles. Supercritical fluid extraction (SFE) has become thus the effective method of separating the mentioned group of compounds. On the other hand, SFE is a beneficial approach in plant waste materials utilization and reduction of environmental burdens caused by the wastes. The aim of the study is to gather and systematize available information on the phenolic compounds separation that have been reported so far as well as to evaluate whether there is one optimal supercritical fluid extraction method for the phenolic compounds.
\end{abstract}

Keywords: anthocyanins; carbon dioxide; extraction techniques; flavonoids; phenolic compounds

\section{Introduction}

The phenolic compounds are of a great interest for different institutions aimed at the applications of phenolics in food, cosmetics and pharmaceutical industries. Seeds, leaves, fruits and roots are the richest sources of not only polyphenols but also other groups of compounds, such as vitamins, fatty acids, triacylglycerols and others [1,2]. The efforts are made to obtain natural antioxidants and replace the synthetic ones that would be extremely beneficial from the viewpoint of health $[3,4]$. The natural products are characterized by thermal instability and high possibility of degradation during all kinds of processing steps [5]. As far as the phenolic compounds are concerned, a number of different extraction techniques has been introduced, with the most frequent being with the use of water and organic solvents (e.g., ethanol, methanol) [6,7]. Ethanol, water and supercritical carbon dioxide are all classified as generally recognized as safe solvents (GRAS) [8]. The choice of an extraction solvent is dependent on the properties of the extracted compounds. Koubaa et al. [9] provide an example of the extraction with hexane as a solvent, obtaining the extract characterized by low phenolic compounds content as a result of low solubility of the phenolic compounds in non-polar solvents. The phenolic compounds have been traditionally extracted using a Soxhlet method but also by soaking and stirring, heat reflux and maceration [10]. Vankar [11] proposed also steam distillation and hydrodistillation. The effectiveness of the extraction is assessed by the extraction selectivity, time, yield and especially the quality of the product obtained (extract) $[12,13]$. In the case of the phenolic compounds extraction, extraction method, chemical nature of compounds extracted as well as storage conditions are the crucial factors [14]. Several drawbacks of the conventional methods of the phenolic compounds extraction have been observed, such as low quality of an extract with unsatisfactory extraction yields but also economic unprofitability of the methods [7]. According to Panja [10], supercritical fluid extraction has been introduced as an efficient and cleaner method compared to other techniques. 
The interest in phenolic compounds has increased even 4-times in the last two decades. This is evidenced by a number of search results with the phrase "phenolic compounds" (Figure 1).

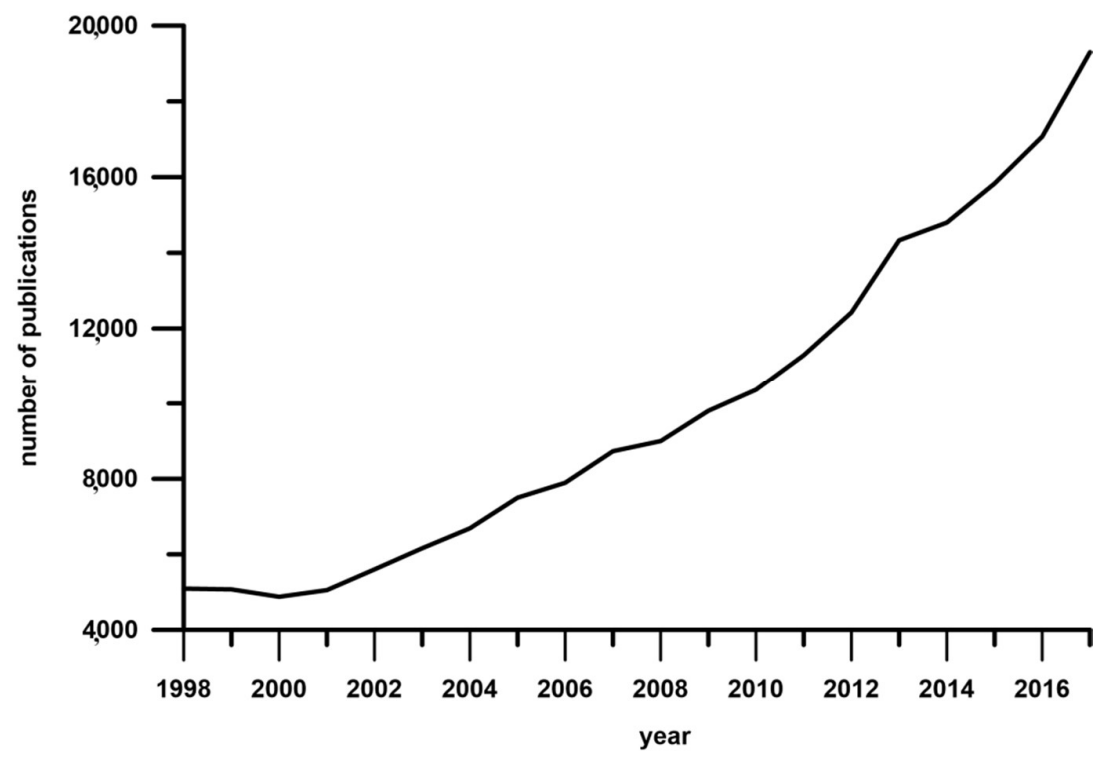

Figure 1. Evolution in the number of papers with the keyword "phenolic compounds" (Science direct, June 2018).

\section{Phenolic Compounds}

The phenolic compounds called secondary metabolites are a group of compounds widely spread in nature [15]. From a chemical point of view, polyphenols are comparable to alcohols in terms of a structure. Both groups of compounds possess hydroxyl groups - $\mathrm{OH}$. However, in flavonoids they are attached to an aromatic ring [16]. The antioxidant properties of polyphenols are mainly attributed to their ability to prevent side reactions via free radicals neutralization [17].

Pereira et al. [16] distinguished two main groups of phenolic compounds, namely phenolic acids and flavonoids. The first group includes benzoic acids derivatives as well as cinnamic acid derivatives. The second group comprises low molecular weight compounds, called flavonoids, which are flavones, flavonols, flavanones, flavan-3-ols, anthocyanidins, isoflavones, coumarins, stilbenes, lignans. The sources of these compounds are leaves, seeds, bark and flowers [18,19]. The concentration of phenolic compounds may differ between the bark and leaves and fruits due to the differences in the exposition to light. As a result, polyphenols are synthesized to a higher extend in fruits which receive a higher dose of sunlight $[20,21]$.

Phenolic compounds are interesting in terms of a broad spectrum of biological properties, including antidiabetic, antioxidant, gastroprotecitve, anti-inflammatory, spasmolytic, antimicrobial, anticarcinogenic [22,23] but also antiseptic, disinfectant [24], hepato-protective, hypotensive and cardioprotective [25]. They have an influence on chronical and degenerative diseases [2] and different types of cancer $[26,27]$. The presence of phenolic compounds in plant materials determines their use in various areas of cosmetic, food and pharmaceutical industries. Different plant materials represent different sources of particular groups of polyphenols. Peels and seeds are considered to be a good source of phenolic acids as well as flavonoids, especially polymethoxylated flavones and the glycosylated flavanones, found mainly in citrus fruits [28]. Berries contain such antioxidants as phenolic acids, flavonoids, hydrolysable and condensed tannins possessing health-promoting properties $[29,30]$. For instance, rutin is the most representative compound in, such materials as elderberry [31].

Some of the flavonoids as well as accompanying carotenoids affect the color of the obtained extract [32]. Rosemary is an interesting material in terms of characteristic phenolic diterpenes, 
among which are i.a. carnosol, carnosoic acid, rosmadial, rosmanol, epirosmanol, isorosmanol [33,34]. Extract of rosemary leaves is used in the food industry as a human nutritional ingredient. Moreover, the effect of extracts on cancer and neurodegenerative diseases has been investigated; [35-37]. The valuable group of anthocyanidins, including cyanidine-3-glucosides, malvidin-3-glucosides and peonidine-3-glucosides may be found in grape peels [38,39], whereas catechin, epicatechin, trans-resveratrol and procyanidin B1 are present in grape seeds [40]. The total content of polyphenols in grapes may be in the range of $60-70 \%$ (wt \%) [41,42]. Apart from phenolic compounds, the plant materials contain also other compounds from the group of carbohydrates, proteins, vitamins and minerals, which are necessary from the nutritive viewpoint [43]. Pigeon pea leaves are known in traditional folk medicine, in which they serve as an agent with expectorant and analgesic properties. The most common compounds are stilbenes, cajaninstilbene acid and pinostrobin [44]. Some of the materials, for instance dandelion, are used as a medicine due to their antidiabetic, antirheumatic and diuretic properties $[45,46]$. Calycopterin belongs to a group of flavonoids present in a high amount in Calyopteris floribunda. It is responsible for anthelmintic and antiviral properties [47]. Among plant materials studied in terms of the phenolic compounds supercritical fluid extraction were Maydis stigma and Pueraria lobata. Both materials are used in Chinese medicine as medicinal herbs. It is due to the presence of alkaloids, saponins, tannins and flavonoids [5]. In case of the latter group, puerarin, daidzin, genistin, daidzein and genistein are identified in the high amount [48].

The studies performed by Liakopolous et al. [49] indicated the presence in peach leaves, such compounds as phenolic acids (caffeic acid, chlorogenic acid, $p$-coumaric acid) (Figure 2), kaempferol, quercetin, isoquercetin and tannin, whereas luteolin, apigenin, luteolin-7-O-glucoside, apigenin-7-O-glucoside and chlorogenic acid are present in common yarrow (Achillea millefolium) [50]. In turn, poplar buds are characterized by the presence of compounds belonging to flavan-3-ols as well as other flavonoids, especially pinostrobin, pinocembrin, galangin and chrysin [51]. Such compounds as cyanidin, delphinidin, malvinidin, peonidin and petunidin are likely to be present in bilberry (Vaccinium myrtillus) [52]. Another interesting group of compounds are prenylflavonoids, with xanthohumol as the most common representative. It is worth mentioning that xanthohumol is present only in hops [53].

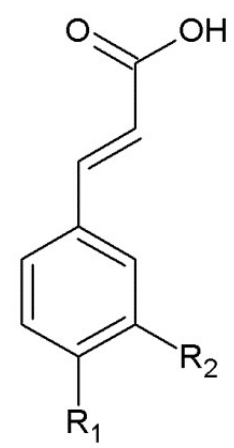

Figure 2. The structure of phenolic acids $\left(\mathrm{R}_{1}=\mathrm{R}_{2}=\mathrm{H}-\right.$ cinnamic acid; $\mathrm{R}_{1}=\mathrm{OH}, \mathrm{R}_{2}=\mathrm{H}-p$-coumaric acid; $\mathrm{R}_{1}=\mathrm{R}_{2}=\mathrm{OH}$ - caffeic acid; $\mathrm{R}_{1}=\mathrm{OH}, \mathrm{R}_{2}=\mathrm{OCH}_{3}$-ferulic acid).

\section{Low-Cost Sources of Phenolic Compounds}

From the economical point of view, the valuable sources for the extraction of phenolic compounds are low-cost products as well as waste materials obtained by all kinds of preparations and industrial processing. One of materials currently of great interest are potato peels, which depending on a variety, contain functional compounds, including those with antioxidant properties [54]. Another example may be spruce bark waste as the by-product of wood processing and forest industry. It is a rich source of phenolic compounds in a form of benzoic acids derivatives (3,4- and 2,4-dihydroxybenzoicacids) (Figure 3) as well as flavonoids (quercetin, taxifolin) and cinnamic acids (ferulic acid, $p$-coumaric acid and sinapic acid) [55-57]. 


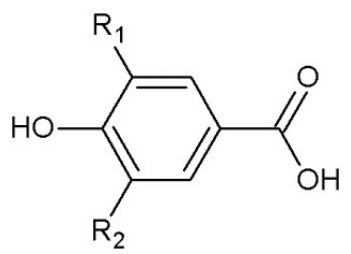

Figure 3. The structure of benzoic acid derivatives $\left(\mathrm{R}_{1}=\mathrm{R}_{2}=\mathrm{H}\right.$-hydroxybenzoic acid; $\mathrm{R}_{1}=\mathrm{OH}, \mathrm{R}_{2}=\mathrm{H}$ - protocatechuic acid; $\mathrm{R}_{1}=\mathrm{OCH}_{3}, \mathrm{R}_{2}=\mathrm{H}$-vanillic acid; $\mathrm{R}_{1}=\mathrm{R}_{2}=\mathrm{OH}$ - gallic acid; $\mathrm{R}_{1}=\mathrm{R}_{2}=\mathrm{OCH}_{3}$ - syringic acid).

Supercritical fluid extraction has found applications in solving problems incurred as a result of treatment and utilization of olive oil mill waste, which is considered as one of the most serious problems affecting environment [58]. Fruit juice production generates the solid waste streams, rich of valuable biologically active compounds, which are extracted with the use of supercritical fluid extraction [31]. The extraction of orange, pomelo, pomegranate by-products, including seeds and peels may give an opportunity to obtain fractions for such industries as food, cosmetic and pharmaceutical ones $[27,59,60]$. Seeds are also a valuable source of unsaturated fatty acids [28]. Wheat germ and soybean cake are by-products of flour milling and soybean oil processing, respectively [61,62]. In the case of soybean, it contains a group of phenolics, called isoflavones (Figure 4). They are attributed to have an influence on heart diseases and osteoporosis as well as postmenopausal symptoms [63-67].<smiles>[R]c1ccc(-c2coc3cc([R])cc([R2])c3c2=O)cc1</smiles>

Figure 4. The structure of isoflavones $\left(\mathrm{R}_{1}=\mathrm{R}_{3}=\mathrm{OH}, \mathrm{R}_{2}=\mathrm{H}\right.$-daidzein; $\mathrm{R}_{1}=\mathrm{O}-\mathrm{Glc}, \mathrm{R}_{2}=\mathrm{H}$, $\mathrm{R}_{3}=\mathrm{OH}$-daidzin; $\mathrm{R}_{1}=\mathrm{R}_{2}=\mathrm{R}_{3}=\mathrm{OH}$-genistein; $\mathrm{R}_{1}=\mathrm{O}-\mathrm{Glc}, \mathrm{R}_{2}=\mathrm{R}_{3}=\mathrm{OH}$-genistin).

\section{Separation of Phenolic Compounds with Supercritical $\mathrm{CO}_{2}$ Extraction}

Supercritical fluid extraction is often used for the extraction of non-polar compounds $[12,66]$. According to Liu et al. [5], it is an alternative technique to conventional extraction techniques, such as Soxhlet and other, owing its advantages to low density and viscosity of supercritical $\mathrm{CO}_{2}$ as well as high diffusivity. Moreover, carbon dioxide is non-flammable and "green", thus it has no significant impact on the environment. The influence of the pressure on the solubility of desired compounds may increase the extraction efficiency. Moreover, carbon dioxide may be more selective when pressure and/or temperature is optimized $[9,67]$. The extraction with pure carbon dioxide provides the final product with no solvent as carbon dioxide is evolved and thus removed during depressurization [68].

\subsection{Applications}

\subsubsection{Pure Carbon Dioxide}

The extraction of phenolic compounds from different plant materials with the use of carbon dioxide in a supercritical state has been studied in the temperature range $25-120^{\circ} \mathrm{C}$ and pressure range 80-655 bar.

Several authors studied the extraction of polyphenols in the temperature range $40-60{ }^{\circ} \mathrm{C}$ at different pressures of carbon dioxide [19,25,57,61,69-77]. Piantino et al. [69] used pure $\mathrm{CO}_{2}$ to extract antioxidant fractions from Baccharis dracunculifolia with optimal conditions of $60^{\circ} \mathrm{C}$ and 400 bar, resulted in 2-times higher yield $(4 \mathrm{mg} / \mathrm{g}$ ) compared to the yield of methanolic and ethanolic extracts. The optimal extraction temperature for blackberry bagasse was also $60^{\circ} \mathrm{C}$ [70]. The highest 
extraction yield $(4.44 \mathrm{mg} / \mathrm{g})$, which was obtained with 200 bar, was comparable to that reported by Piantino et al. [69]. The temperature of $60^{\circ} \mathrm{C}$ and the pressure of 235 bar guaranteed the highest efficiency of supercritical fluid extraction for purslane (Portulaca oleracea) seeds [71]. In some cases the highest yield of the extraction does not correspond to the highest phenolic content. As it was studied by Chatterjee et al. [74], the temperature of $40{ }^{\circ} \mathrm{C}$ and the pressure of 350 bar resulted in the highest yield $(8.51 \mathrm{mg} / \mathrm{g})$ of Phormidium valderianum extraction. However, the content of phenolic compounds (55.98 mg GAE/g) was 2-times lower compared to the one in the extraction at the temperature of $50{ }^{\circ} \mathrm{C}$ and 350 bar (117.15 mg GAE/g). Comparing supercritical fluid extraction with the Soxhlet method, Bimakr et al. [19] achieved the same results for the extraction of spearmint leaves with two methods. The conditions for the SFE method were $60^{\circ} \mathrm{C}$ and 200 bar, whereas the Soxhlet method was performed with 70\% aqueous ethanol. The content of particular phenolics, including catechin, epicatechin, rutin, myricetin, luteolin, apigenin and naringenin was similar in both cases.

Depending on the extracted material, the antioxidant fraction was extracted at constant temperature of $40{ }^{\circ} \mathrm{C}$ and at different pressures, generally in the range 100-300 bar [41,50,76,78,79]. Only Feliciano et al. [66] performed the cranberries fruits extraction under the pressure of 655 bar. Carvalho et al. [76] and Wu et al. [79] performed studies on rosemary leaves and wine lees, respectively at the same conditions with the temperature of $40{ }^{\circ} \mathrm{C}$ and pressure of 300 bar. However, in the latter studies the extraction yield was 2-times higher $(11.9 \%(w / w)$ vs. 5.0\% $(w / w))$. The difference might be caused by the diversity of the phenolic compounds and their variable content in the extracted materials.

Concerning the number of publications, the extraction of rosemary (Rosmarinus officinalis) leaves to obtain phenolic compounds fraction was studied the most [33,37,75,76,80-83]. In this case, the studies were performed in the temperature range $25-110{ }^{\circ} \mathrm{C}$ and pressure range $80-1000$ bar. Among all performed studies Nguyen et al. [84] used the highest pressures (500-1000 bar) for the extraction with pure $\mathrm{CO}_{2}$. In the first step, an essential oil fraction was extracted at the pressure of $115 \mathrm{bar}$ and the temperature of $40{ }^{\circ} \mathrm{C}$. In the second step, they reported optimal conditions for phenolic compounds extraction from rosemary leaves of 300 bar and the temperature in the range $90-100{ }^{\circ} \mathrm{C}$ as the further temperature increase was not efficient and enhanced thermal decomposition of the extracted compounds [84]. The temperature of $25^{\circ} \mathrm{C}$ was not appropriate as it provided the total phenolic content of $120 \mathrm{mg}$ per gram (as gallic acid equivalent) that was 2-times lower in comparison to the extraction performed at $50{ }^{\circ} \mathrm{C}$ under constant pressure of 80 bar. The optimal conditions in this case were the last mentioned $\left(50^{\circ} \mathrm{C}, 80\right.$ bar) [85]. Generally, the extraction may be reproducible when it is performed at similar conditions. Ivanović et al. [80] and Babovic et al. [33] reported rosemary leaves extraction at $100{ }^{\circ} \mathrm{C}$ and 300 and 350 bar, which resulted in the similar extraction yield of, respectively, $1.57 \%$ and $1.33 \%(w / w)$. Babovic et al. [33] extracted also sage (Salvia officinalis), thyme (Thymus vulgaris) and hyssop (Hyssop officinalis) at the same conditions with the extraction yields of $1.53 \%, 1.58 \%$ and $1.08 \%(w / w)$, respectively. Decreasing the temperature to $50{ }^{\circ} \mathrm{C}$ while increasing the carbon dioxide density at the constant pressure of 300 bar provides the best results in terms of the extraction yield $(33 \%, w / w)$ of rosemary leaves extract compared to the results provided by the authors only as wt \% [37].

Kuś et al. [51], Gelmez et al. [61] and Espinosa-Pardo et al. [73] performed similar studies in which they utilized supercritical fluid extraction with pure $\mathrm{CO}_{2}$ at the temperature of $60^{\circ} \mathrm{C}\left(58^{\circ} \mathrm{C}\right.$ in [61]) and the pressure 300, 336 and 300 bar, respectively. In the case of peach (Prunus persica) fruits extraction, the conditions $\left(60^{\circ} \mathrm{C}, 300 \mathrm{bar}\right)$ which enabled to obtain the highest yield of phenolic compounds $(4.9 \mathrm{wt} \%)$ were different from the conditions for obtaining the highest yield of carotenoids $\left(40^{\circ} \mathrm{C}, 200 \mathrm{bar}\right)$ [73]. In the case of Strobilanthes crispus, pomegranate (Punica granatum), mango (Magnifera indica), Theobroma cacao, Undaria pinnnatifida and bran, researchers performed the extractions with the highest yield in the temperature of $50^{\circ} \mathrm{C}$ and in the pressure range $100-350$ bar $[77,81-83,86,87]$.

Another crucial parameter affecting the extraction of phenolic compounds is pressure. Studies performed by $\mathrm{Wu}$ et al. [45] indicated that increasing the pressure from 250 bar to 300 bar led to the increase of the cranberries herb extraction yield as well. However, further increase of the pressure 
above 300 bar decreased the efficiency of the extraction and consequently decreased the total yield. The pressure effect was explained by higher density of supercritical carbon dioxide at higher pressures. Kryževičiute et al. [88] investigated a similar influence of pressure on the phenolic extraction from raspberry pomace. At constant temperature of $60^{\circ} \mathrm{C}$, increasing the pressure from 100 bar to 450 bar resulted in 14-times higher extraction yield (from $0.01 \mathrm{wt} \%$ to $14.61 \mathrm{wt} \%$ ). As it was pointed out by $\mathrm{Wu}$ et al. [45], the temperature increase lowers the density of carbon dioxide. However, Kryževičiute et al. [88] increased both the temperature and pressure to obtained optimal density of carbon dioxide to extract the phenolic compounds from raspberry (Rubus sp.) pomace with the highest yield. The lowest yield in the range $0.01-2.59 \%(w / w)$ was obtained when the pressure was 100 bar at each studied temperature $\left(30,45,60^{\circ} \mathrm{C}\right)$.

The phenolic compounds fraction was also obtained at higher temperature and pressure compared to previously described studies. The optimal conditions for grape seeds extraction were $104{ }^{\circ} \mathrm{C}$ and 538 bar [40]. Povilaitis et al. [89] performed the extraction of rye (Secale cereale) at the pressure of 550 bar with relatively low temperature $\left(70^{\circ} \mathrm{C}\right)$ than in the previous mentioned studies by Romabaut et al. [40].

The non-polar nature of carbon dioxide may be affected by the addition of a polar modifier. In the studies aimed at the comparison of the extraction of polyphenols with pure carbon dioxide and modified carbon dioxide, the most common modifiers were methanol, ethanol, water and isopropyl alcohol [54,57,90-95]. The influence of a modifier is best illustrated by the results of the research conducted by Leitao et al. [91]. The extraction of Anacardium occidentale with pure $\mathrm{CO}_{2}$ was compared with the extraction with $\mathrm{CO}_{2}$ with either $5 \%(w / w)$ isopropyl alcohol or $5 \%(w / w)$ ethanol at the temperature of $45{ }^{\circ} \mathrm{C}$ and pressure of 200 bar. The processes resulted in the extraction yield of $0.71 \%$ (pure $\left.\mathrm{CO}_{2}\right), 1.03 \%\left(\mathrm{CO}_{2}+\mathrm{iPrOH}\right)$ and $1.3 \%\left(\mathrm{CO}_{2}+\mathrm{EtOH}\right)$. However, the highest yield $(1.6 \%)$ was obtained when the extraction was performed at lower temperature $\left(35^{\circ} \mathrm{C}\right)$ and lower pressure (100 bar) with $0.5 \%(w / w)$ ethanol. The authors compared also the supercritical fluid extraction method with conventional extraction method, such as Soxhlet with ethanol as a solvent. The yield $(14.3 \mathrm{wt} \%)$ was over 10-times higher for the Soxhlet method in terms of the extraction yield when compared to a number of SFE methods with pure $\mathrm{CO}_{2}$, isopropyl alcohol and ethanol (0.7-1.6 wt \%). De Azevedo et al. [92] performed the extraction of green coffee beans with pure $\mathrm{CO}_{2}$ as well as with $5 \%(w / w)$ of isopropyl alcohol or $5 \%(w / w)$ of ethanol as modifiers. The highest yield of $17 \%$ was obtained for the extraction with carbon dioxide and ethanol. The differences in using isopropyl alcohol and ethanol were observed in the selectivity and the detection of particular compounds. In the case of caffeine, its content was lower when the extraction was performed with isopropyl alcohol, whereas chlorogenic acid was not extracted with ethanol at all. Chang et al. [93] focused on the extraction of catechins from green tea at the temperature of $50{ }^{\circ} \mathrm{C}$ and pressure 310 bar.

Senorans et al. [75] provided the application of supercritical fluid extraction of rosemary leaves with the addition of $2 \%(v / v)$ ethanol at the temperature of $40{ }^{\circ} \mathrm{C}$ and pressure $300 \mathrm{bar}$. Cavero et al. [90] studied a higher range of the ethanol content $(4 \%, 7 \% v / v)$ in the carbon dioxide mixture in the extraction of rosemary leaves. The differences between the extraction with pure carbon dioxide and modified carbon dioxide were significant in terms of the extraction yields, which were in the range $3.93-6.78 \%$ when ethanol was used. The pure carbon dioxide extraction yields were several times lower and amounted to $0.03-0.013 \%$. Similarly, for the extraction of wine by-products, Louli et al. [95] employed supercritical fluid extraction with modified carbon dioxide. Methanol was used as a modifier in the amount of $5 \%(v / v)$. The extraction with methanol $\left(45^{\circ} \mathrm{C}, 250\right.$ bar) resulted in total phenolic content of $5.6 \%(w / w)$ and was 3 times lower than the extraction with pure $\mathrm{CO}_{2}$ at the temperature of $45^{\circ} \mathrm{C}$ and the pressure of 150 bar. Two times higher extraction pressure (297.52 bar) and $44.39^{\circ} \mathrm{C}$ were optimal in the sage herbal dust extraction as was reported by Pavlić et al. [96]. López-Padilla et al. [97] studied the influence of temperature $\left(40,70{ }^{\circ} \mathrm{C}\right)$ and pressure $(200,300 \mathrm{bar})$ on the Vaccinium meridionale extraction. Table 1 includes applications of pure carbon dioxide in phenolic compounds extraction from different plant materials. 
Table 1. Applications of pure $\mathrm{CO}_{2}$ in phenolic compounds extraction.

\begin{tabular}{|c|c|c|c|c|c|c|}
\hline \multirow{2}{*}{ Plant } & \multirow{2}{*}{ Part of the Plant } & \multicolumn{3}{|c|}{ Extraction Conditions } & \multirow{2}{*}{ TPC (Total Phenolic Content) * } & \multirow{2}{*}{ Reference } \\
\hline & & Solvent & Temperature $\left[{ }^{\circ} \mathrm{C}\right]$ & Pressure [bar] & & \\
\hline Acai (Euterpe oleracea) & berries & $\mathrm{CO}_{2}$ & $50-70$ & $150-490$ & $137.5 \mathrm{mg} / 100 \mathrm{~g}$ (anthocyanins) & [98] \\
\hline Achillea millefolium & leaves & $\mathrm{CO}_{2}$ & 40 & $100-200$ & $125-152.1 \mathrm{mg} / \mathrm{g}$ & {$[50]$} \\
\hline Baccharis dracunculifolia & leaves & $\mathrm{CO}_{2}$ & $40-60$ & $200-400$ & n.d. & [69] \\
\hline Blackberry (Rubus sp.) & bagasse & $\mathrm{CO}_{2}$ & $40-60$ & $150-250$ & $3.31-4.44 \mathrm{mg} / \mathrm{g}$ & {$[70]$} \\
\hline Black poplar (Populus nigra) & buds & $\mathrm{CO}_{2}$ & 60 & 300 & $31.09 \mu \mathrm{g} / \mathrm{mg}$ & [51] \\
\hline Cranberries & fruits & $\mathrm{CO}_{2}$ & 40 & 655 & n.d. & [66] \\
\hline Dandelion (Taraxacum officinale) & herb & $\mathrm{CO}_{2}$ & $40-60$ & $200-400$ & n.d. & [45] \\
\hline Dorema aucheri & herb & $\mathrm{CO}_{2}$ & $40-60$ & $150-450$ & n.d. & [72] \\
\hline \multirow{4}{*}{ Grape } & seeds & $\mathrm{CO}_{2}$ & $35-60$ & $50-150$ & $15.6-22.56 \mathrm{~g} / \mathrm{kg}$ & {$[41]$} \\
\hline & seeds & $\mathrm{CO}_{2}$ & $75-104$ & $230-538$ & $190-350 \mathrm{mg} / \mathrm{g}$ & {$[40]$} \\
\hline & marc & $\mathrm{CO}_{2}$ & 40,45 & 100,120 & $300.9 \mathrm{mg} / \mathrm{g}$ & [99] \\
\hline & wine lees & $\mathrm{CO}_{2}$ & 40 & 350 & $11.9 \%(w / w)$ & {$[79]$} \\
\hline Green tea & leaves & $\mathrm{CO}_{2}$ & 50,70 & $100-300$ & $530-578 \mathrm{mg} / \mathrm{g}$ & {$[100]$} \\
\hline Houttuynia cordata & grass & $\mathrm{CO}_{2}$ & 40 & 200 & n.d. & {$[78]$} \\
\hline Hyssop (Hyssop officinalis) & leaves & $\mathrm{CO}_{2}$ & 100 & 350 & n.d. & {$[33]$} \\
\hline Mango (Magnifera indica) & leaves & $\mathrm{CO}_{2}$ & $40-50$ & $100-400$ & n.d. & {$[82]$} \\
\hline Moringa oleifera & leaves & $\mathrm{CO}_{2}$ & $40-60$ & $100-200$ & n.d. & {$[25]$} \\
\hline Olive oil & mill waste & $\mathrm{CO}_{2}$ & 40 & 350 & $0.76 \%(w / w)$ & {$[58]$} \\
\hline Peach (Prunus persica) & fruits & $\mathrm{CO}_{2}$ & $40-60$ & $100-300$ & n.d. & [73] \\
\hline Phormidium valderianum & algae & $\mathrm{CO}_{2}$ & $40-60$ & $200-500$ & $117.15 \mu \mathrm{g} / \mathrm{g}$ & [74] \\
\hline Pomegranate (Punica granatum) & leaves & $\mathrm{CO}_{2}$ & 40,50 & $100-300$ & $257-389 \mathrm{mg} / \mathrm{g}$ & {$[81]$} \\
\hline Purslane (Portulaca oleracea) & seeds & $\mathrm{CO}_{2}$ & 60 & 235 & $173 \mathrm{mg} / \mathrm{g}$ & {$[71]$} \\
\hline Raspberry (Rubus sp.) & pomace & $\mathrm{CO}_{2}$ & $30-60$ & $100-450$ & n.d. & {$[88]$} \\
\hline
\end{tabular}


Table 1. Cont

\begin{tabular}{|c|c|c|c|c|c|c|}
\hline \multirow{6}{*}{ Rosemary (Rosmarinus officinalis) } & \multirow{6}{*}{ leaves } & $\mathrm{CO}_{2}$ & 40,100 & 300 & n.d. & [80] \\
\hline & & $\mathrm{CO}_{2}$ & 100 & 350 & n.d. & [33] \\
\hline & & $\mathrm{CO}_{2}$ & 50 & $150-400$ & $33 \%(w / w)$ & [37] \\
\hline & & $\mathrm{CO}_{2}$ & $25-50$ & $80-120$ & $230 \mathrm{mg} / \mathrm{g}$ & [85] \\
\hline & & $\mathrm{CO}_{2}$ & $30-40$ & $100-300$ & n.d. & [76] \\
\hline & & $\mathrm{CO}_{2}$ & 90-110 & $500-1000$ & n.d. & [84] \\
\hline Rye (Secale cereale) & bran & $\mathrm{CO}_{2}$ & $30-70$ & $250-550$ & $14.62 \mathrm{mg} / \mathrm{g}$ & [89] \\
\hline \multirow{3}{*}{ Sage (Salvia officinalis) } & \multirow{2}{*}{ leaves } & $\mathrm{CO}_{2}$ & 100 & 350 & n.d. & [33] \\
\hline & & $\mathrm{CO}_{2}$ & 40,100 & 300 & n.d. & [80] \\
\hline & herbal dust & $\mathrm{CO}_{2}$ & $40-60$ & $100-300$ & n.d. & [96] \\
\hline Spearmint (Mentha spicata) & leaves & $\mathrm{CO}_{2}$ & $40-60$ & $100-300$ & n.d. & [19] \\
\hline Strobilanthes crispus & leaves & $\mathrm{CO}_{2}$ & $40-60$ & $100-200$ & n.d. & [77] \\
\hline Theobroma cacao & hulls & $\mathrm{CO}_{2}$ & 50 & $100-200$ & n.d. & [83] \\
\hline Thyme (Thymus vulgaris) & leaves & $\mathrm{CO}_{2}$ & 100 & 350 & n.d. & [33] \\
\hline Wheat germ & - & $\mathrm{CO}_{2}$ & $40-60$ & $148-602$ & $6 \mathrm{mg} / \mathrm{g}$ extract & [62] \\
\hline Wine & lees & $\mathrm{CO}_{2}$ & 40 & 300 & $11.9 \%(w / w)$ & [79] \\
\hline $\begin{array}{l}\text { Whole flour, medium oat bran, fine } \\
\text { bran, low bran }\end{array}$ & commercial & $\mathrm{CO}_{2}$ & 50 & 350 & n.d. & [87] \\
\hline Vaccinium meridionale & berries & $\mathrm{CO}_{2}$ & 40,70 & 200,300 & n.d. & [97] \\
\hline
\end{tabular}

${ }^{*}$ Total phenolic content is provided as gallic acid equivalent, other equivalents than that are provided in the brackets. n.d —no data. 


\subsubsection{Modified Carbon Dioxide}

Carbon dioxide is characterized by its non-polar nature and it is said to be less capable of dissolving polyphenols, which are, on the other hand, polar compounds [13]. However, the extraction efficiency as well as solvent power of carbon dioxide may be increased by the addition of a polar co-solvent such as e.g., ethanol, methanol or water [66,100]. The addition of the co-solvent is based on the hydrogen bonds formation as well as dipole-dipole or dipole induced dipole interactions between co-solvent and an analyte but also affects the extraction by the solvent-co-solvent interaction $[27,101]$. Ivanović et al. [80] proved that the use of modifiers is efficient at particular pressures. In the case of the extraction of Lamiaceae herbs, the pressure of 500 bar and higher affected the selectivity of carbon dioxide resulting in a decrease of the antioxidant activity. Table 2 presents the applications of co-solvent modified carbon dioxide in phenolic compounds extraction.

Table 2. Applications of co-solvent modified $\mathrm{CO}_{2}$ in phenolic compounds extraction.

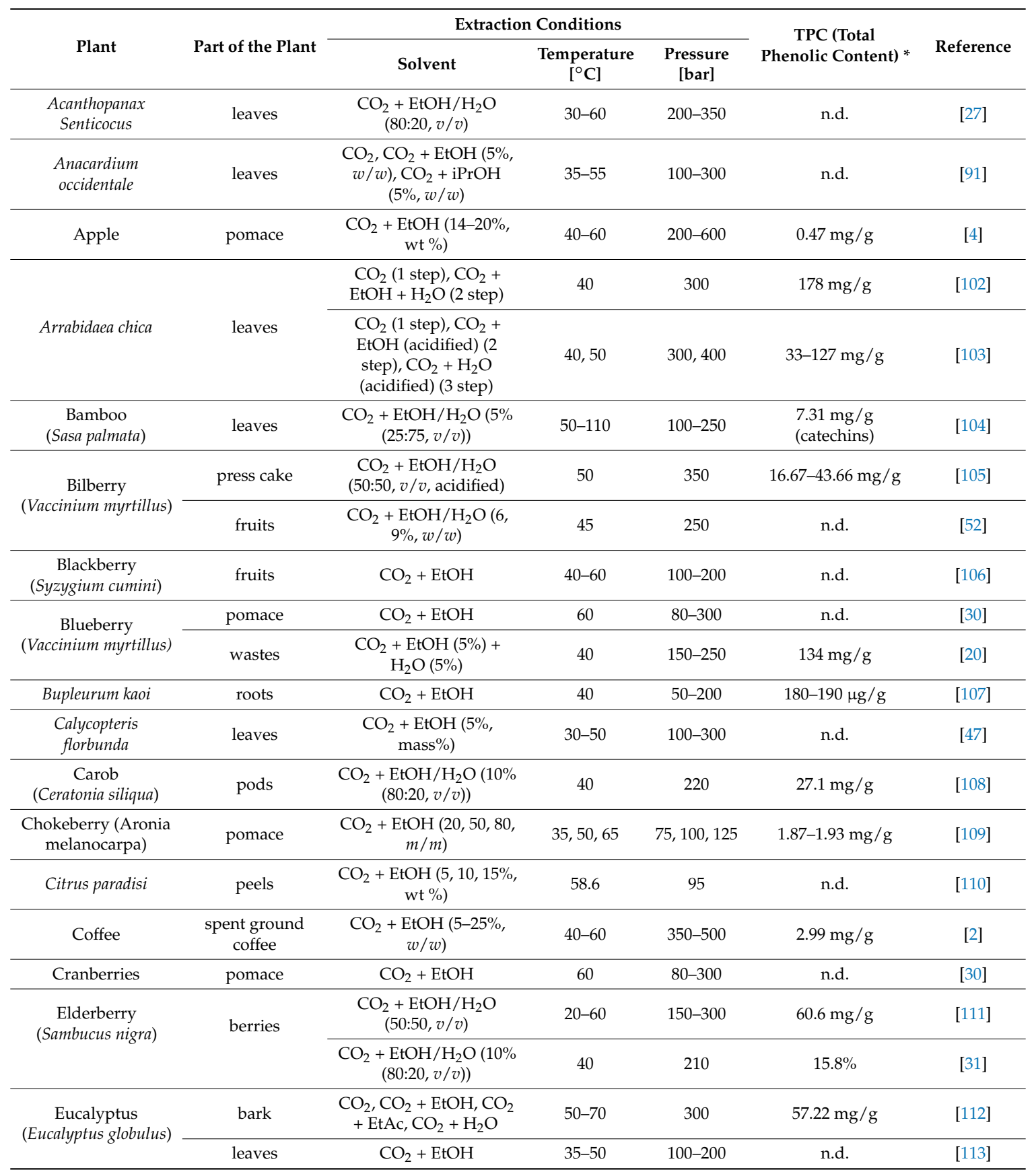


Table 2. Cont

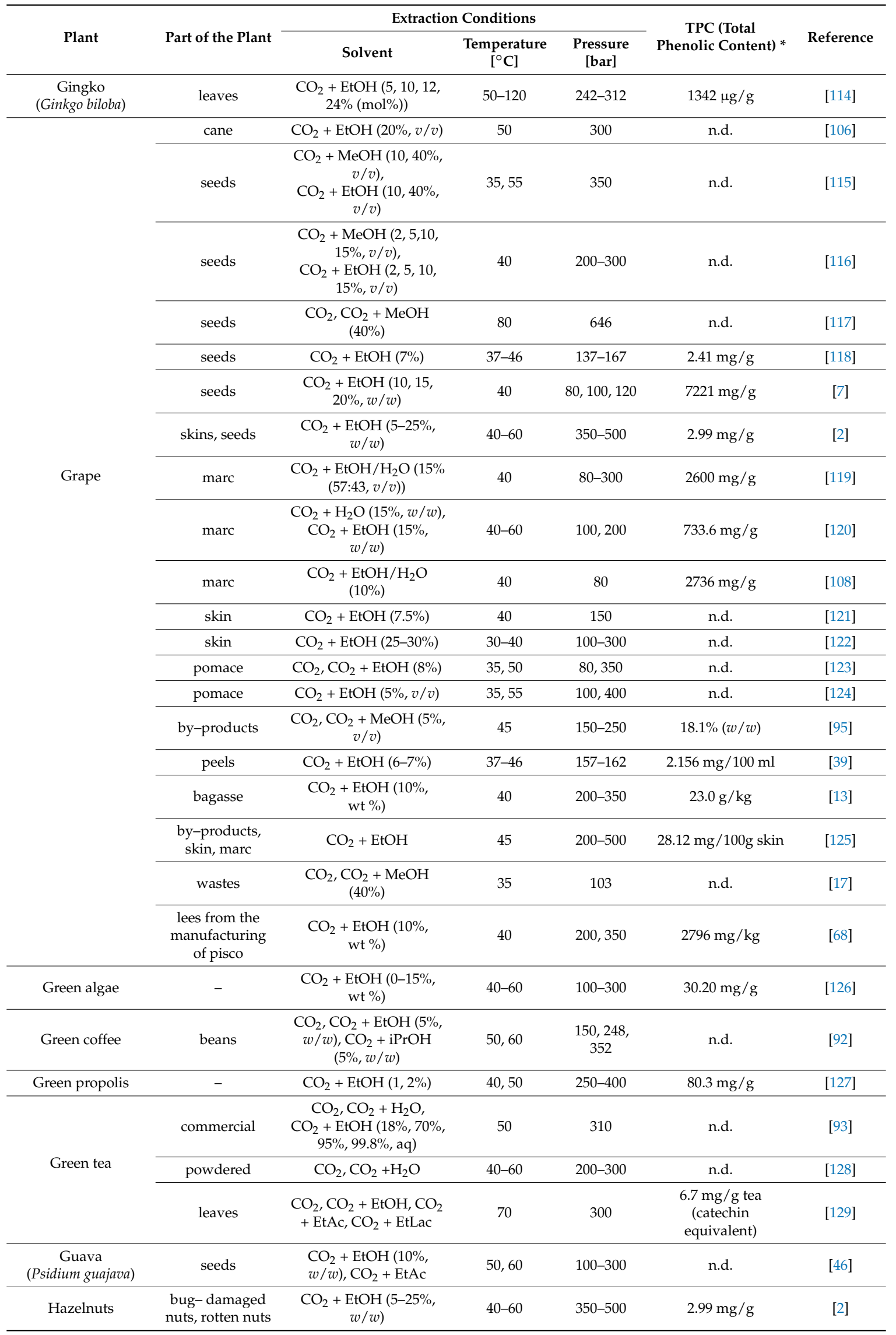


Table 2. Cont

\begin{tabular}{|c|c|c|c|c|c|c|}
\hline \multirow[b]{2}{*}{ Plant } & \multirow[b]{2}{*}{ Part of the Plant } & \multicolumn{3}{|c|}{ Extraction Conditions } & \multirow{2}{*}{$\begin{array}{c}\text { TPC (Total } \\
\text { Phenolic Content) * }\end{array}$} & \multirow[b]{2}{*}{ Reference } \\
\hline & & Solvent & $\begin{array}{l}\text { Temperature } \\
{\left[{ }^{\circ} \mathrm{C}\right]}\end{array}$ & $\begin{array}{l}\text { Pressure } \\
\text { [bar] }\end{array}$ & & \\
\hline $\begin{array}{c}\text { Jatoba } \\
\text { (Hymenaea courbail) }\end{array}$ & bark & $\mathrm{CO}_{2}+\mathrm{H}_{2} \mathrm{O}(9: 1, v / v)$ & $50-60$ & $150-350$ & $\begin{array}{l}335 \mathrm{mg} / \mathrm{g} \text { (tannic } \\
\text { acid equivalent) }\end{array}$ & [23] \\
\hline Koreanum nakai & leaves & $\begin{array}{c}\mathrm{CO}_{2}+\mathrm{EtOH}(70: 30 \\
v / v)\end{array}$ & $40-70$ & $200-350$ & n.d. & [132] \\
\hline Maydis stigma & flowers & $\mathrm{CO}_{2}+\mathrm{EtOH}(20 \% \mathrm{aq})$ & $40-60$ & $250-450$ & $3.99 \mathrm{mg} / \mathrm{g}$ & [5] \\
\hline Melia azedarach & fruits & $\begin{array}{c}\mathrm{CO}_{2}, \mathrm{CO}_{2}+\mathrm{EtOH} \\
\mathrm{EtOH}, \mathrm{EtOH}+\mathrm{H}_{2} \mathrm{O}\end{array}$ & 50 & 300 & $\begin{array}{c}35 \mathrm{mg} / \mathrm{g} \text { (catechin } \\
\text { equivalent) }\end{array}$ & [133] \\
\hline \multirow{2}{*}{$\begin{array}{c}\text { Myrtle } \\
\text { (Myrthus communis) }\end{array}$} & leaves & $\begin{array}{c}\mathrm{CO}_{2}, \mathrm{CO}_{2}+\mathrm{EtOH} \\
(0-30 \%, \text { wt } \%)\end{array}$ & $35-60$ & $100-300$ & $\begin{array}{c}4 \mu \mathrm{mol} / \mathrm{g} ; 16 \\
\mu \mathrm{mol} / \mathrm{g}\end{array}$ & [94] \\
\hline & leaves, berries & $\mathrm{CO}_{2}+\mathrm{EtOH}$ & 45 & 230 & n.d. & [24] \\
\hline Odontonema strictum & leaves & $\mathrm{CO}_{2}+\mathrm{EtOH}(15 \%)$ & 55,65 & 200,250 & $99.33-247.78 \mathrm{mg} / \mathrm{g}$ & {$[135]$} \\
\hline Oats (Avena sativa) & - & $\begin{array}{c}\mathrm{CO}_{2}+\mathrm{EtOH}(80: 20 \\
v / v)\end{array}$ & $40-70$ & $140-620$ & $1.25 \mathrm{mg} / \mathrm{g}$ & [136] \\
\hline Olive & leaves & $\mathrm{CO}_{2}+\mathrm{MeOH}(10 \%)$ & 100 & 334 & n.d. & [137] \\
\hline $\begin{array}{c}\text { Orange } \\
\text { (Citrus sinensis) }\end{array}$ & pomace & $\begin{array}{c}\mathrm{CO}_{2}, \mathrm{CO}_{2}+\operatorname{EtOH}(2,5 \\
8 \%, w / w)\end{array}$ & 40,50 & $100-300$ & $36 \mathrm{mg} / \mathrm{g}$ & [59] \\
\hline Patrinia villosa & - & $\mathrm{CO}_{2}+\mathrm{MeOH}(10,20 \%)$ & $45-60$ & $150-350$ & n.d. & [138] \\
\hline $\begin{array}{c}\text { Pistachio (Pistachia } \\
\text { vera) }\end{array}$ & hulls & $\begin{array}{c}\mathrm{CO}_{2}, \mathrm{CO}_{2}+\mathrm{MeOH}(5 \\
15 \%)\end{array}$ & $35-55$ & $100-350$ & $\begin{array}{l}7.8 \mathrm{mg} / \mathrm{g} \text { (tannic } \\
\text { acid equivalent) }\end{array}$ & [140] \\
\hline $\begin{array}{c}\text { Pitanga (Eugenia } \\
\text { uniflora) }\end{array}$ & leaves & $\begin{array}{c}\mathrm{CO}_{2} \text { (1 step), } \mathrm{CO}_{2}+ \\
\mathrm{EtOH}(2 \text { step }), \mathrm{CO}_{2}+ \\
\mathrm{H}_{2} \mathrm{O}(3 \text { step })\end{array}$ & 60 & 400 & $240.5 \mathrm{mg} / \mathrm{g}$ & [18] \\
\hline $\begin{array}{c}\text { Pomegranate } \\
\text { (Punica granatum) }\end{array}$ & seeds & $\begin{array}{c}\mathrm{CO}_{2}+\mathrm{H}_{2} \mathrm{O}(0,9,18 \\
\mathrm{ml} / 100 \mathrm{~g} \text { sample), } \mathrm{CO}_{2} \\
+\mathrm{EtOH}(0,9,18 \mathrm{ml} / 100 \\
\mathrm{g} \text { sample }), \mathrm{CO}_{2}+ \\
\text { hexane }(0,9,18 \mathrm{~mL} / 100 \\
\text { g sample) }\end{array}$ & $40-60$ & $\begin{array}{l}200,275 \\
350\end{array}$ & $\begin{array}{l}7.8-72.1 \mathrm{mg} / \mathrm{g} \\
\text { (tannic acid } \\
\text { equivalent) }\end{array}$ & {$[26]$} \\
\hline $\begin{array}{c}\text { Pomelo } \\
\text { (Citrus grandis) }\end{array}$ & peels & $\begin{array}{c}\mathrm{CO}_{2}+\underset{\mathrm{EtOH}}{(85: 15} \\
v / v)\end{array}$ & $60-80$ & $280-420$ & n.d. & {$[60]$} \\
\hline Puearia lobata & roots & $\begin{array}{c}\mathrm{CO}_{2}+\mathrm{EtOH}(100,200 \\
\mathrm{mL})\end{array}$ & $40-60$ & $150-250$ & $\begin{array}{l}173.3 \mathrm{mg} / \mathrm{g} \\
\text { (flavonoids) }\end{array}$ & [48] \\
\hline \multirow{3}{*}{$\begin{array}{l}\text { Purple corn } \\
\text { (Zea mays) }\end{array}$} & cob, pericarp & $\begin{array}{c}\mathrm{CO}_{2} \text { (1 step), } \mathrm{CO}_{2}+ \\
\mathrm{EtOH}(2 \text { step }), \mathrm{CO}_{2}+ \\
\mathrm{H}_{2} \mathrm{O}(3 \text { step })\end{array}$ & 50 & 400 & n.d.. & [141] \\
\hline & cobs & $\begin{array}{c}\mathrm{CO}_{2}+\mathrm{EtOH} / \mathrm{H}_{2} \mathrm{O}(50 \\
70 \% \text { aq })\end{array}$ & 50 & 400 & $290 \mathrm{mg} / \mathrm{g}$ & [8] \\
\hline & $\mathrm{cob}$ & $\begin{array}{c}\mathrm{CO}_{2} \text { (1 step), } \mathrm{CO}_{2}+ \\
\mathrm{EtOH}(2 \text { step }), \mathrm{CO}_{2}+ \\
\mathrm{H}_{2} \mathrm{O}(3 \text { step })\end{array}$ & $36-64$ & $259-541$ & n.d. & {$[142]$} \\
\hline
\end{tabular}


Table 2. Cont.

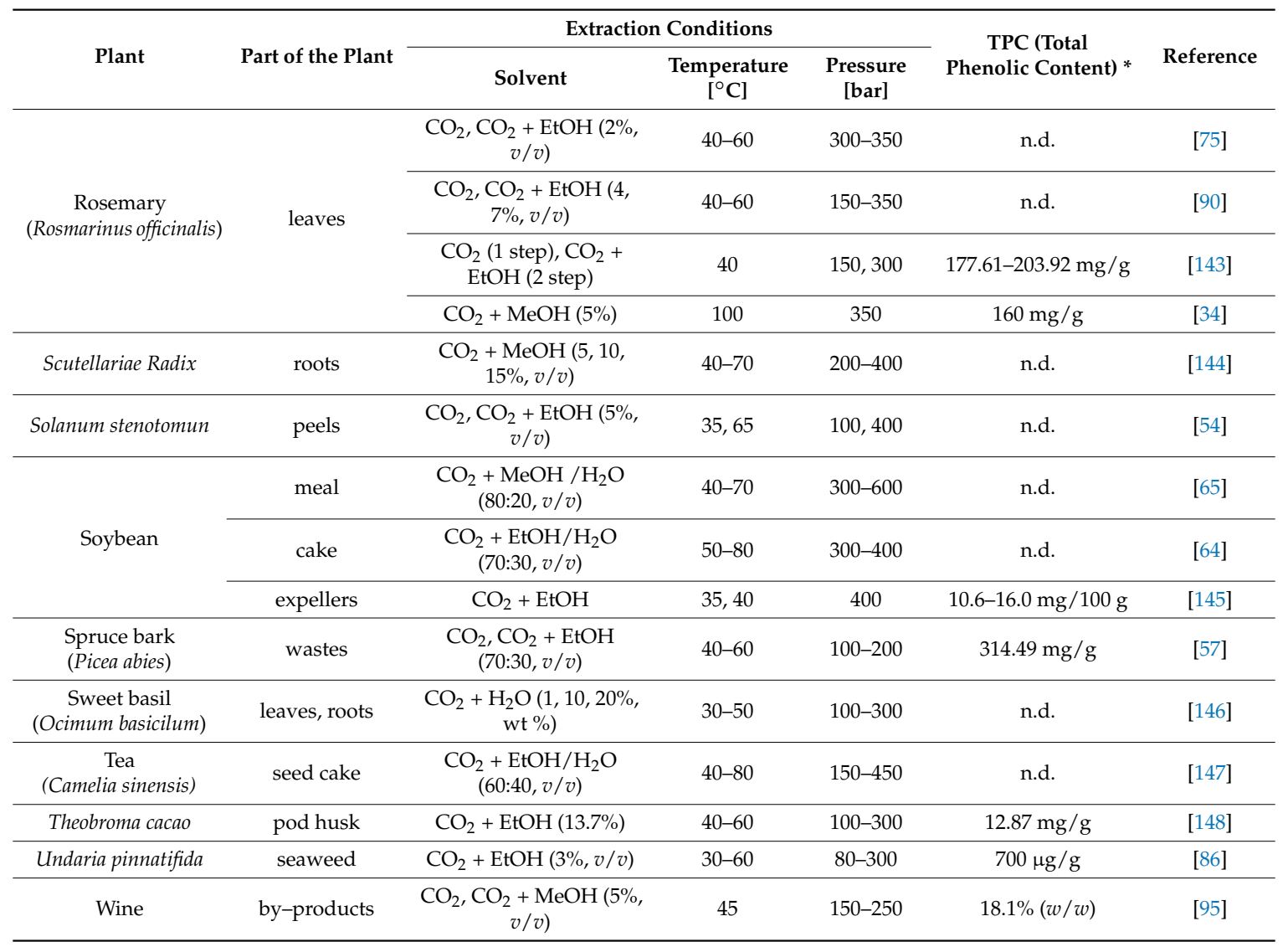

* Total phenolic content is provided as gallic acid equivalent, other equivalents than that are provided in the brackets. n.d —no data, EtOH—ethanol, $\mathrm{MeOH}$ - methanol, $\mathrm{H}_{2} \mathrm{O}$ - water, EtAc—ethyl acetate, EtLac — ethyl lactate, iPrOH—isopropyl alcohol.

The studies performed with the use of the supercritical fluid extraction may be grouped into five methods based on a type of a modifier: (a) pure and aqueous ethanol, (b) water, (c) sequential extraction with carbon dioxide, ethanol and water, (d) methanol, (e) other solvents (hexane, ethyl acetate, ethyl lactate, isopropyl alcohol). The most frequent extractions were performed with carbon dioxide and ethanol, either aqueous or pure $[2,4,13,27,39,47,59,68,86,106,139]$. The studies included the temperature range $20-80^{\circ} \mathrm{C}$, pressure range $80-600$ bar as well as a different content of ethanol in carbon dioxide/ethanol mixtures. Manna et al. [2] extracted polyphenols from grape pomace at the temperature of $40^{\circ} \mathrm{C}$ and the pressure of 200 bar. The content of ethanol was investigated in the range $5-25 \%(w / w)$. The results showed no improvement in the extraction yield with the increase of the ethanol content. Similar studies were performed by Ghaffor et al. [39] on grape peels with the optimal content of ethanol being ca. 6-7\%. Different results were obtained in the studies by Adil et al. [4] and Kazan et al. [139]. In the first studies, the addition of 20\% (wt \%) ethanol was required to obtain the highest total phenolic content $(0.427 \mathrm{mg} \mathrm{GAE} / \mathrm{g}$ for apple pomace and $0.25 \mathrm{mg}$ GAE$/ \mathrm{g}$ for peach pomace). The optimal extraction conditions were $50^{\circ} \mathrm{C}$ and 600 bar. Kazan et al. [139] applied lower pressure of $150 \mathrm{bar}$ and $60^{\circ} \mathrm{C}$ in the extraction of peach (Prunus persica) leaves. The extraction with $6 \%$ (wt \%) ethanol yielded the phenolic content of $79.92 \mathrm{mgGAE} / \mathrm{g}$. In a comparison, $30.66 \mathrm{mgGAE} / \mathrm{g}$ were obtained when $20 \%$ (wt \%) ethanol was used with carbon dioxide.

Some of the authors performed the extraction at the temperature of $40{ }^{\circ} \mathrm{C}$ and in the pressure range 150-500 bar with pure ethanol content ranging from 0 to $15 \%(w / w)[13,68,110,118,121,125]$. In both studies by Farias-Campomanes et al. [13,68], the same conditions were employed that resulted in the highest extraction yield of grape bagasse and lees $\left(40{ }^{\circ} \mathrm{C}, 200 \mathrm{bar}, 10 \mathrm{wt} \%\right.$ ethanol). In both cases, increasing the pressure to 400 and 350 bar, respectively, decreased the efficiency even 2-times. 
The same amount of ethanol (10 wt \%) guaranteed the highest yield of Citrus paradisi extraction (58.6 ${ }^{\circ} \mathrm{C}, 95$ bar) in the studies by Giannuzzo et al. [110]. The mixture of carbon dioxide with $7.5 \%$ of ethanol was also used in the studies by Pascual-Marti et al. [121] and less than 7\% of ethanol in studies by Ghafoor et al. [118] on the extraction of grape skin and seeds, respectively. Fiori et al. [125] used the highest pressure of 500 bar with the temperature of $45^{\circ} \mathrm{C}$ to extract grape by-products.

The best results for the extraction $\left(50{ }^{\circ} \mathrm{C}, 350\right.$ bar) of green propolis were reported by Machado et al. [127], using $\mathrm{CO}_{2}$ with a relatively low content of ethanol (1\%). A different effect of processing parameters on Undaria pinnatifida seaweed extraction of phenolic compounds was also observed by Roh et al. [86]. The best conditions for obtaining the fucoxanthin rich fraction were $50{ }^{\circ} \mathrm{C}$ and 200 bar, whereas phenolic compounds rich fraction was obtained at $60{ }^{\circ} \mathrm{C}$ and under 250 bar. The authors used the mixture of carbon dioxide and $3 \%(v / v)$ ethanol. As for the extraction of green algae, the optimal conditions were $40^{\circ} \mathrm{C}, 300$ bar and carbon dioxide with 11.4 wt \% ethanol [126]. However, the fraction with the highest polyphenols content was obtained at different conditions, involving $60^{\circ} \mathrm{C}, 300$ bar and $7.5 \%$ of ethanol as was demonstrated by Fabrowska et al. [126]. Valandez-Carmona et al. [148] reported studies on Theobroma cacao extraction in which conditions were provided $\left(60^{\circ} \mathrm{C}, 300 \mathrm{bar}\right)$ that resulted in both highest extraction yield $(0.47 \%)$ and at the same time highest total phenolic content as compared, for instance, with studies on green algae by Fabrowska et al. (60 ${ }^{\circ} \mathrm{C}, 300$ bar) [126].

In some cases, the temperature did not influence the extraction of the phenolic compounds. Ouédraogo et al. [135] obtained the highest total phenolic content (247.78 $\mathrm{mg} \mathrm{GAE} / \mathrm{g})$ at $55^{\circ} \mathrm{C}$ and 250 bar in Odontonema strictum leaves extract. Higher temperature $\left(65^{\circ} \mathrm{C}\right)$ resulted in a lower content of the polyphenols (121.99 mg GAE/g). Liu et al. [27] also investigated the effect of the temperature on the polyphenols extraction from Acanthopanax senticocus. The optimal conditions involved the temperature range from 35 to $50{ }^{\circ} \mathrm{C}$. The increase of the pressure between $320-340$ bar also increased the extraction yield to some extent. However, as stated by the authors, such conditions influence more the financial aspect of the extraction. Pinelo et al. [123] compared the extraction of grape pomace under the same conditions $\left(50{ }^{\circ} \mathrm{C}, 350\right.$ bar) with pure $\mathrm{CO}_{2}$ and modified $\mathrm{CO}_{2}$ (with $8 \%$ of ethanol). In this case, ethanol did not lead to the highest content of phenolic compounds. The extraction with pure $\mathrm{CO}_{2}$ resulted in the polyphenols concentration of $572.8 \mathrm{ppm}$, whereas $432.5 \mathrm{ppm}$ with modified $\mathrm{CO}_{2}$. Similar studies were reported by Benelli et al. [59]. The ethanol content was the same, while the orange (Citrus sinensis) extraction was conducted at the pressure of 250 bar, which in this case resulted in more than 2 times higher extraction yield $(3.0 \% w / w)$ than that obtained with pure carbon dioxide. Casas et al. [124] performed studies aimed at obtaining the resveratrol-rich fraction from grape pomace at the temperature of $55^{\circ} \mathrm{C}$ and under the pressure of 100 bar without and with a modifier $(5 \%, v / v$ ethanol). At the same conditions, resveratrol was not identified in the fraction obtained with pure carbon dioxide. Da Porto et al. [119] studied different concentrations $(7.5,10,15 \%)$ of ethanol/water mixtures $(57: 43, v / v)$. The highest grape marc extraction yields were obtained when $7.5 \%$ of the mixture was used at $40{ }^{\circ} \mathrm{C}$ and 80 bar. It was observed that with a higher concentration of ethanol/water mixture (10\%), the extraction yield was slightly lower (2527 $\mathrm{mg}$ GAE/100 g) than that with $7.5 \%$ of the mixture $(2600 \mathrm{mg} \mathrm{GAE} / 100 \mathrm{~g})$. The highest content of ethanol (25-30\%) in carbon dioxide/ethanol mixture was used by Bleve et al. [122]. The grape skins extraction was performed under liquid as well as subcritical conditions, which enabled to determine the optimal temperature between $30-40{ }^{\circ} \mathrm{C}$. Zachova et al. [149] reported the addition of $20 \%(v / v)$ ethanol as optimal in the extraction of grape cane at the temperature of $50{ }^{\circ} \mathrm{C}$ and the pressure of $300 \mathrm{bar}$.

Another method has been applied for the extraction of antioxidants from Solanum stenotomun. The temperature of $65{ }^{\circ} \mathrm{C}$ and pressure of 400 bar with $5 \%(v / v)$ ethanol enabled to obtain the yield of $1 \%$, which was the highest yield of the extraction. The highest content of anthocyanins was obtained at the pressure of 100 bar [54]. The highest yield $(30.46 \%, w / w)$ for the extraction of spruce bark wastes was obtained using supercritical fluid extraction with carbon dioxide with the addition of the ethanol. The temperature was $40{ }^{\circ} \mathrm{C}$ and pressure 100 bar. However, the highest total phenolic 
content was reached when the extraction was performed at higher temperature of $60^{\circ} \mathrm{C}$. While the extraction was studied in the temperature range $40-60^{\circ} \mathrm{C}$, in each case the phenolic compounds were extracted within first $15 \mathrm{~min}$ [57]. The highest extraction yield (7.54\%) was obtained from Calyopteris floribunda leaves when 5\% (mass\%) of ethanol was added to carbon dioxide at the temperature of $35^{\circ} \mathrm{C}$ and 300 bar [47]. Other plant materials, such as gingko (Gingko biloba) [114], Bupleurum kaoi [107], Momordica charantia [134], blackberry (Syzygium cumini) [106] as well as eucalyptus [113] were studied in the temperature range $35-60{ }^{\circ} \mathrm{C}$ and the pressure range $50-350$. The highest content of flavonoids (15 mg/g) was analyzed by Shan et al. [134]. The combination of carbon dioxide and 5\% of aqueous solution of ethanol $\left(\mathrm{EtOH} / \mathrm{H}_{2} \mathrm{O}: 25: 75, v / v\right)$ provided the highest amount of polyphenols $(7.31 \mathrm{mg} / \mathrm{g}$ as catechin equivalent) in the extraction of bamboo (Sasa palmata) leaves at the temperature of $95^{\circ} \mathrm{C}$ and the pressure of 200 bar [104].

Some of the researchers studied the influence of carbon dioxide with $50 \%$ aqueous solution of ethanol [105,111,131] and even 60\% aqueous solution of ethanol [147]. Del Pilar Garcia-Mendoza et al. [131] as well as Kerbstadt et al. [105] applied the acidified mixture of ethanol and water in the extraction of jucara (Euterpe edulis) and bilberry (Vaccinium myrtillus) press cake extraction, respectively. In the studies performed by Vatai et al. [111], the optimal conditions which guaranteed the highest total phenolic content of $60.6 \mathrm{mg} / \mathrm{g}$ were $40{ }^{\circ} \mathrm{C}$ and $150 \mathrm{bar}$. The authors investigated the effect of the temperature increase from 20 to $60{ }^{\circ} \mathrm{C}$, which resulted in a different amount of anthocyanins. In the studies reported by Li et al. [147] on the extraction of tea (Camelia sinensis) seed cake, the extraction was conducted at the temperature of $80^{\circ} \mathrm{C}$ with $60 \%$ aqueous ethanol. The pressure of 200 bar was required to obtain the satisfactory extraction efficiency. In a comparison with the studies performed by Li et al. [147], Woźniak et al. [109] performed the extraction with carbon dioxide and ethanol (20, 50, $80 \%, m / m$ ) as a modifier. The optimal conditions for the Chokeberry (Aronia melanocarpa) extraction were $35{ }^{\circ} \mathrm{C}, 100$ bar and $80 \%(\mathrm{~m} / \mathrm{m})$ of ethanol. The temperature of $35^{\circ} \mathrm{C}$ was also optimal in the soybean expellers extraction conducted by Alvarez et al. [145]. However, higher pressure (400 bar) was required for obtaining the highest extraction yield.

The studies were also performed with the water content of $30 \%$ and less in ethanol/water mixtures $[44,60,128,128,129,131]$. The extractions were performed in the temperature range $35-80{ }^{\circ} \mathrm{C}$ and pressure range 220-390 bar. C.M. Liu et al. [132] combined carbon dioxide with $70 \%(v / v)$ of aqueous ethanol with the same pressure of 300 bar but different temperature, including $35{ }^{\circ} \mathrm{C}$. Moreover, Li et al. [147] compared 70\% aqueous ethanol and pure ethanol as a modifier. In this case Koreanum nakai leaves extraction yield for $70 \%(v / v)$ ethanol was $5.4 \%$, whereas $3.4 \%$ was obtained with pure ethanol. The mixture of ethanol/water with the content of ethanol of $85 \%(v / v)$ was effective in the extraction of polyphenols from pomelo (Citrus grandis) peels at different temperatures, with the highest one $\left(80^{\circ} \mathrm{C}\right)$ being used by He et al. [60]. Roseiro et al. [150], He et al. [130], Escobedo-Flores et al. [136] and Kong et al. [44] employed the extractions at following conditions $40{ }^{\circ} \mathrm{C} / 220$ bar (carob (Ceratonia siliqua)), $50{ }^{\circ} \mathrm{C} / 250$ bar (hops (Humulus lupulus)), $55^{\circ} \mathrm{C} / 380$ bar (oats (Avena sativa)) and $60{ }^{\circ} \mathrm{C} / 300$ bar (pigeon pea (Cajanus cajan)), respectively. All studies were performed with $80 \%(v / v)$ aqueous ethanol. Paes et al. [20] used $90 \%$ carbon dioxide and both $5 \%$ of ethanol and $5 \%$ of water to extract blueberry (Vaccinium myrtillus) wastes. The authors observed that different compositions of carbon dioxide/co-solvent mixture were required for highest extraction yield $\left(50 \% \mathrm{CO}_{2}+50 \% \mathrm{H}_{2} \mathrm{O}\right)$ and highest total phenolic content $\left(90 \% \mathrm{CO}_{2}+5 \% \mathrm{EtOH}+5 \% \mathrm{H}_{2} \mathrm{O}\right)$. Both studies were performed at the temperature of $40{ }^{\circ} \mathrm{C}$ and the pressure of 200 bar. Da Porto et al. [120] optimized the extraction conditions for the polyphenols extraction from grape marc with $\mathrm{scCO}_{2}+15 \% \mathrm{H}_{2} \mathrm{O}(w / w)$ and scCO $+15 \% \mathrm{EtOH}(w / w)$. As for the first method, the temperature and pressure were $40{ }^{\circ} \mathrm{C}$ and $100 \mathrm{bar}$, whereas for the second $50{ }^{\circ} \mathrm{C}$ and 100 bar. However, the best results were obtained when the combined extraction was applied. The first step was to extract grape marc with $\mathrm{CO}_{2} / \mathrm{H}_{2} \mathrm{O}$ with the same concentration as earlier followed by $\mathrm{CO}_{2} / \mathrm{EtOH}$. The extraction resulted in a total phenolic content of $733.6 \mathrm{mg}$ GAE per $100 \mathrm{~g}$ of the material. In the consecutive studies, da Porto et al. [108] employed carbon dioxide with much lower content of ethanol (10\%) in the ethanol/water mixture in the extraction 
of grape marc. In this case, such conditions with the temperature of $40{ }^{\circ} \mathrm{C}$ and the pressure of 80 bar enabled to obtain best results.

In some cases, the use of supercritical fluid extraction may not be limited only to extract phenolic compounds. In the studies by Stevenson et al. [151], they did not separate phenolic compounds from oats (Avena sativa) by supercritical fluid extraction. They applied SFE as the pre-treatment stage, in which the carbon dioxide may be used to remove the lipids from the sample at the temperature of $85{ }^{\circ} \mathrm{C}$ and pressure of $689 \mathrm{bar}$ and prepare the sample in this way for further separation. The oats (Avena sativa) bran was then extracted with $50 \%$ aqueous solution of ethanol and pure ethanol. The highest extraction yield $(9.2 \mathrm{mg} / \mathrm{g})$ was slightly higher than that obtained with pure ethanol $(9.0$ $\mathrm{mg} / \mathrm{g})$.

The extraction with carbon dioxide modified by water may be the next option for the extraction of phenolic compounds $[23,128,146]$. Huang et al. [128] extracted powdered green tea and obtained the extracts which were characterized by the highest content of catechins and at the same time the highest content of caffeine. The optimal temperature and pressure were $60^{\circ} \mathrm{C}$ and 300 bar, respectively. Similar results were reported by Veggi et al. [23]. The extraction of jatoba (Hymenaea courbail) bark was performed in the temperature range $50-60{ }^{\circ} \mathrm{C}$ and pressure range $150-350$ bar. Leal et al. [146] optimized conditions for the extraction of sweet basil leaves for different addition of water $(1,10$, $20 \mathrm{wt} \%$ ) to carbon dioxide. As for $1 \%(\mathrm{wt} \%)$ of water, the temperature was $30^{\circ} \mathrm{C}$ and the pressure was 100 bar. For $10 \%$ ( $w t \%$ ) of water, $30^{\circ} \mathrm{C}$ and $100-150$ bar were the optimal conditions, whereas $20 \%\left(\mathrm{wt} \%\right.$ ) of water required the temperature of $30^{\circ} \mathrm{C}$ but a higher pressure of 300 bar compared to previous conditions. Babova et al. [52] tested three solvent mixtures at the temperature of $45^{\circ} \mathrm{C}$ and the pressure of 250 bar. Carbon dioxide was modified by $6 \%(w / w)$ of the ethanol/water mixtures with ethanol content of $70 \%$ and $50 \%$ as well as $9 \%(w / w)$ of the ethanol/water mixture with ethanol content of $10 \%(w / w)$. The latter were the best conditions for the extraction of polyphenols from bilberry (Vaccinium myrtillus).

Da Porto et al. [108] indicated that the best results were obtained when the extraction was performed in sequential steps. Such studies were also performed by other groups of researchers $[18,52,102,103,133,141-143]$. The studies were aimed at the extraction of particular materials first with pure carbon dioxide, then the residue extraction with the mixture of ethanol and water and finally the residue extraction from step 2 with water. In both extraction methods proposed by Paula et al. [102,103], the extracted material was Arrabidaea chica leaves. In the first study, the process was applied with two-step extraction $\left(\mathrm{CO}_{2}, \mathrm{CO}_{2}+\mathrm{EtOH}+\mathrm{H}_{2} \mathrm{O}\right)$, whereas in the second one pure $\mathrm{CO}_{2}$ was followed by $\mathrm{CO}_{2}+\mathrm{EtOH}$ and $\mathrm{CO}_{2}+\mathrm{H}_{2} \mathrm{O}$ as two separate steps. Monroy et al. [141,142] applied in their studies on purple corn (Zea mays) three-step extraction $\left(\mathrm{CO}_{2}, \mathrm{CO}_{2}+\mathrm{EtOH}, \mathrm{CO}_{2}+\mathrm{H}_{2} \mathrm{O}\right)$. Among studied temperatures $\left(36-64{ }^{\circ} \mathrm{C}\right.$ ) and pressures (259-541 bar), the optimal conditions were $65^{\circ} \mathrm{C}$ and 440 bar based on the response surface methodology. Del Pilar Sánchez-Camargo et al. [143] used two-step extraction of rosemary leaves with pure carbon dioxide and then with addition of $7 \%$ of ethanol, which enhanced the extraction efficiency. The extractions were performed at the temperature of $40{ }^{\circ} \mathrm{C}$ and 100 bar (only pure carbon dioxide) as well as 300 bar (pure carbon dioxide, carbon dioxide with ethanol). Bitencourt et al. [133] added one more step in the extraction of Melia azedarach fruits. The process was performed with pure carbon dioxide and then with carbon dioxide and ethanol followed by pure ethanol and finally with water.

Methanol is the third solvent that has been used commonly as carbon dioxide modifier. Different concentrations of methanol $(0-40 \%, v / v)$ as well as aqueous methanol were studied (70, $80 \%)[17,34,66,95,115-117,137,138,140,144]$. In the case of temperature and pressure, studies included the ranges of $35-100^{\circ} \mathrm{C}$ and $100-646$ bar, respectively. The highest temperatures of $80^{\circ} \mathrm{C}$ and $100{ }^{\circ} \mathrm{C}$ were applied by Khorassani et al. [117], Le Floch et al. [137] and Celiktas et al. [34] to extract phenolic compounds fraction from grape seeds, olive leaves and rosemary leaves, respectively. The optimal methanol concentration was $40 \%, 10 \%$ and 5\%, respectively. Grape seeds were extracted with the highest pressure of 646 bar among all studies performed with carbon dioxide and methanol [117]. 
The highest methanol concentration of $40 \%$ was also effective in the extraction of grape wastes with relatively low temperature $\left(35^{\circ} \mathrm{C}\right)$ and pressure (103 bar) [17]. Phenolic compounds were not detected in the fractions obtained with pure carbon dioxide $\left(35^{\circ} \mathrm{C}, 100\right.$ bar as well as $\left.45^{\circ} \mathrm{C}, 200 \mathrm{bar}\right)$. The addition of $5 \%$ methanol to carbon dioxide at the temperature of $45^{\circ} \mathrm{C}$ and the pressure of $100 \mathrm{bar}$ resulted in the same effect as with pure carbon dioxide. The increase of methanol to $15 \%$ and the pressure to 350 bar increased also the pistachio (Pistachia vera) extraction efficiency to the highest total phenolic content (7.8 mg tannic acid/g) level [140].

The concentration of methanol has also an effect on particular compounds extraction from grape seeds. The lowest concentration $(2 \%, v / v)$ enabled to extract low molecular compounds. However, the increase of the concentration to $10 \%(v / v)$ resulted in the identification of epicatechin gallate in the obtained fractions [116]. Palma and Taylor [115] and Louli et al. [95] indicated 5-10\% $(v / v)$ of methanol as the one which provides the best results in the extraction of grape seeds and grape by-products. Louli et al. [95] performed extraction of grape by-products at the temperature of $45^{\circ} \mathrm{C}$ and under 250 bar. The same conditions $\left(45^{\circ} \mathrm{C}, 250\right.$ bar) were used by Peng et al. to extract Patrinia villosa [138]. Both Lin et al. [144] and Zuo et al. [66] combined carbon dioxide with $70 \%$ and $80 \%$ aqueous methanol, which provided the best extraction yield in the extraction of Scutellariae radic and soybean, respectively.

Apart from ethanol, water and methanol, which are the most commonly used as modifiers, other solvents were also tested, such as ethyl acetate, ethyl lactate and hexane [26,46,112,129]. Ethanol occurred to be better solvent than ethyl acetate and water in the studies on eucalyptus (Eucalyptus globulus) by Santos et al. [112] and guava (Psidium guajava) by Castro-Vargas et al. [46]. Different results were reported by Bermejo et al. [129]. In their studies, extraction of green tea leaves with carbon dioxide and ethyl lactate resulted in the highest caffeine yield. Abbasi et al. [26] indicated water as carbon dioxide modifier which provided the largest amount of phenolic compounds in the fraction obtained from pomegranate (Punica granatum). Hexane was the one which provided the poorest extraction efficiency. Figure 5 presents a schematic diagram of phenolic compounds extraction from various plant sources using pure and modified carbon dioxide.

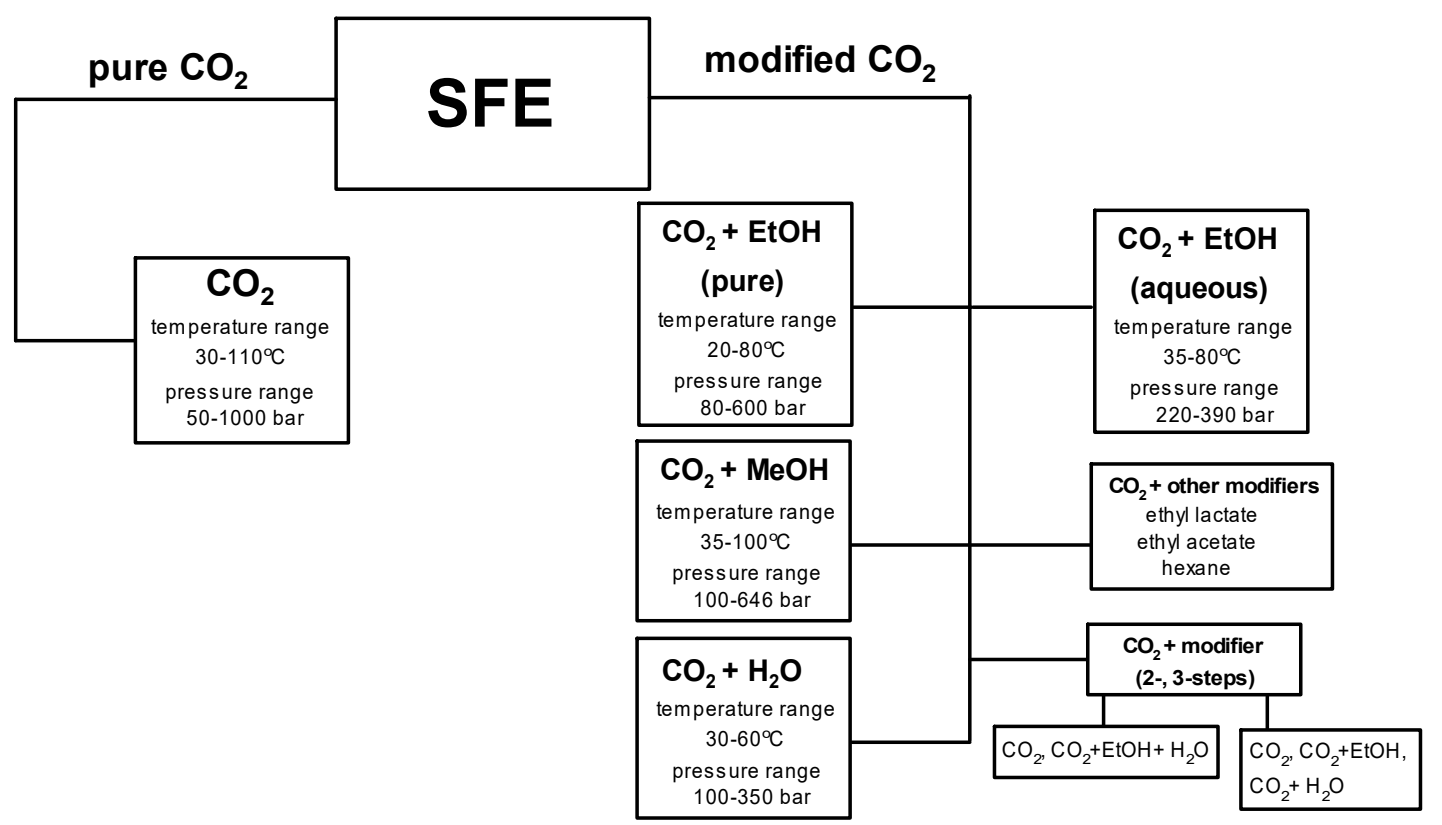

Figure 5. Application of SFE in phenolic compounds extraction from plant materials.

\section{Combined SFE}

Supercritical fluid extraction (SFE) has found an application in the phenolic compounds extraction with the use of pure carbon dioxide as well as carbon dioxide with an addition of either polar or non-polar modifiers. Additionally, several other techniques (both extraction and chromatographic) 
have the potential to be used for obtaining fractions rich in polyphenols. Some of the used combinations are SFE-SFC (supercritical fluid extraction-supercritical fluid chromatography) [152,153], SFE-HPLC-MS/MS (supercritical fluid extraction-mass spectrometry liquid chromatography) [154], SFE-GC (supercritical fluid extraction-gas chromatography) [155], SFE-FTIR (supercritical fluid extraction-fourier transform infrared spectroscopy) [156], SFE-SPE (supercritical fluid extraction-solid phase extraction) [152], SFE-PLE (supercritical fluid extraction-pressurized liquid extraction) [106] but also US-SFE (ultra sound assisted supercritical fluid extraction) and SFE-DLLME (supercritical fluid extraction-dispersive liquid-liquid microextraction) [157].

Concerning the SFE-SFC system, both solvent in SFE and mobile phase in SFC are combined in the same physical state in order to extract, fractionate as well as identify and quantify desired compounds [152]. A successful application of SFE-SFC-MS/MS has been reported by Liu et al. [153] with the optimal extraction conditions of $50{ }^{\circ} \mathrm{C}$ and 9 minutes in an off-line mode. The extraction of 15 phenolic compounds from garlic required the addition of 30\% methanol. The chromatographic separation was conducted with the use of Shim-pack UCX Diol (150 mm $\times 4.6 \mathrm{~mm} ; 3 \mu \mathrm{m})$ column packed with silica modified by diol groups as well as carbon dioxide and methanol (with ammonium formate) as the mobile phase components. The obtained SFE fractions were rich in ferulic acid, $p$-coumaric acid, naringenin, apigenin, protocatechuic acid, isorhamnetin, luteolin, phthalic acid, quercetin, chlorogenic acid and resveratrol. As it was indicated by Hofstetter et al. [158], the use of on-line SFE-SFC is limited by the analysis duration as well as sample transfer performed in a split mode in order to reduce the extraction volume, which in consequence has an influence on final results and sample amount. Another interesting chromatographic technique coupled to supercritical fluid extraction was used by Hawthorne et al. [155]. The SFE-GC-FID was applied in the extraction and identification of phenolics from hardwood smoke with the extraction temperature of $50{ }^{\circ} \mathrm{C}$ and the pressure of 400 bar.

As far as SFE coupled to other extraction techniques is concerned, Zachová et al. [106] compared SFE with PLE (pressurized liquid extraction) method. Moreover, combined SFE-PLE system was applied to stilbenes extraction from grape cane. The conditions of PLE method for resveratrol isolation involved the temperature of $100^{\circ} \mathrm{C}$ and the pressure of 100 bar, whereas SFE method required $60^{\circ} \mathrm{C}$ and 300 bar with the addition of ethanol (15-20\%) as a modifier. The obtained SFE-PLE fractions were characterized by different concentrations of stilbenes depending on the extraction parameters. As it was concluded by the authors, further optimization is required in terms of pressure and temperature in SFE method and the composition of the solvent or solvents mixtures in PLE method [106].

\section{SFE among Other Green Extraction Methods}

The advantages of SFE lie in the health and safety but also cost and environmental impact in general. The properties of carbon dioxide are particularly influential when thermolabile compounds are to be extracted [159]. Moreover, as it was discussed in this paper, SFE is an effective system for waste materials management not only reducing wastes but also reducing solvent and energy consumption. In addition to SFE, other modern green extraction techniques include ultrasound-assisted extraction (UAE), microwave-assisted extraction (MAE), pressurized liquid extraction (PLE) and pressurized hot water extraction (PHWE) [15,160]. Panja [10] adds also other techniques, such as enzyme assisted extraction (EAE) and pulsed electric field extraction (PEF), whereas sub-critical water extraction (SCWE) and high hydrostatic pressure processing (HHPP) are the techniques proposed by Khoddami et al. [161].

Rodríguez-Solana et al. [162] compared SFE and MAE in terms of the total phenolic content in the extracts of Mentha piperita, Origanum vulgare, Rosmarinus officinalis and Thymus vulgaris. The SFC method was used with carbon dioxide as well as methanol $(3 \%, v / v)$ as a modifier, however, higher TPC value was obtained by ASE method in all four extracts $(4.09,3.04,1.67$ and $0.42 \mathrm{~g} \mathrm{GAE} / 100 \mathrm{~g}$ dry plant for ASE vs $0.02,0.13,0.11$ and $0.07 \mathrm{~g}$ GAE $/ 100 \mathrm{~g}$ dry plant for SFE). The comparison of SFE and MAE was also performed by Llopmart et al. [163] on the example of the phenolic compounds 
extraction from various soil matrices. The obtained results indicated a higher recovery for garden soil $(111 \%)$ and endesa soil (85\%) extraction in the case of MAE method. The garden soil and endesa soil extraction with the use of SFE resulted in the recovery of $88 \%$ and $77 \%$, respectively.

Roseiro et al. [108] have reported the superiority of SFE over UAE method in the extraction of carob (Ceratonia siliqua) pods. The UAE method was performed with two solvents, such as $100 \% \mathrm{H}_{2} \mathrm{O}$ and 70\% acetone. The higher TPC was analyzed when acetone was used as a solvent (20.4 mg GAE/g vs $9.4 \mathrm{mg} \mathrm{GAE} / \mathrm{g})$. The SFC was conducted at the temperature of $40^{\circ} \mathrm{C}$ and pressure of 220 bar with the addition of $10 \% \mathrm{EtOH} / \mathrm{H}_{2} \mathrm{O}(80: 20, v / v)$. TPC in the obtained extract was measured in the amount of $27.1 \mathrm{mg} \mathrm{GAE} / \mathrm{g}$. In the studies performed by Dias et al. [164], SFE combined with US appeared to be more effective in the phenolic compounds extraction of pepper (Capsicum baccatum) in a comparison with a single SFE. The optimal conditions for SFE-US method were $40{ }^{\circ} \mathrm{C}, 150$ bar and $200 \mathrm{~W}$. The TPC value obtained for SFE $\left(60^{\circ} \mathrm{C}, 250\right.$ bar) extract was 3 times lower than for SFE-US extract $(0.23 \mathrm{mg}$ EAG/g vs $0.62 \mathrm{mg}$ EAG/g). Benelli et al. [59] obtained similar TPC for SFE and UAE in the extracts from orange (Citrus sinensis). The values of TPC were $30 \mathrm{mg} \mathrm{GAE} / \mathrm{g}$ and $37 \mathrm{mg} \mathrm{GAE} / \mathrm{g}$, respectively for SFE and UAE. The temperature of $50{ }^{\circ} \mathrm{C}$ and pressure of 250 bar with carbon dioxide modified by ethanol $(8 \%, v / v)$ were the optimal conditions for the highest extraction yield. Among studied MAE solvents, such as hexane, ethyl acetate, ethanol, water and dichloromethane, the latter was the most effective.

A number of publications on the comparison of SFE with PLE method, has been reported by Taamalli et al. [164], Anaëlle et al. [165], Kraujaliene et al. [166] and Fernández-Ponce et al. [167]. In first two studies, better results were obtained for the PLE method. The global extraction yields of mango leaves were 37\% and 8\%, respectively for PLE and SFE [167]. In the case of PLE method proposed by Anaëlle et al. [165], different compositions of ethanol/water mixtures $\left(\mathrm{EtOH} / \mathrm{H}_{2} \mathrm{O}, 75: 25, v / v\right.$; $\left.\mathrm{EtOH} / \mathrm{H}_{2} \mathrm{O}, 25: 75, v / v\right)$ did not significantly influence TPC values, which were around $10 \%$ of dry weight. SFE at the temperature of $60^{\circ} \mathrm{C}$ and pressure of 152 bar with the addition of $12 \%(v / v)$ ethanol resulted in 2 times lower TPC (around 5\% of dry weight). In some cases, SFE and SFE-PLE provide similar TPC values as was proved by Kraujaliene et al. [166] on the example of goldenrod (Solidago virgaurea) extraction with TPC around 169-185 mg GAE/g. The combination of acetone with either $70{ }^{\circ} \mathrm{C}$ or $140{ }^{\circ} \mathrm{C}$ in PLE and carbon dioxide with $70{ }^{\circ} \mathrm{C}$ in SFE-PLE method were used. Taamalli et al. [168] extracted six different Tunisian olive leaves with the use of SFE $\left(40^{\circ} \mathrm{C}\right), \mathrm{MAE}$ (methanol/water, 80:20, $v / v ; 80^{\circ} \mathrm{C}$ ) and PLE (ethanol; water, $150^{\circ} \mathrm{C}, 100$ bar). The obtained results were different in terms of the species and methods.

\section{Conclusions}

Literature review included the extractions of phenolic compounds pure carbon dioxide as well as co-solvent modified carbon dioxide. The studies showed a very high interest in polyphenols extraction using supercritical fluid extraction. Pure supercritical carbon dioxide is a safe solvent for this purpose. However, together with ethanol, the extraction efficiency may be enhanced significantly. One should emphasize that the highest extraction yields did not correspond to the highest total phenolic content in all cases. Obviously, co-solvent modified supercritical $\mathrm{CO}_{2}$ is more efficient and mostly used in phenolic compounds extraction. The evidence in the number of $\mathrm{CO}_{2}$ /co-solvent extraction publications representing almost $70 \%$ of all described in the review studies, may be a good determinant as well as the confirmation of co-solvent use effectiveness to some extent. The review systematically reflects the issues connected with phenolic compounds extraction. The scattered results from various publications have been gathered into one paper.

According to gathered information in terms of total phenolic content, it is hardly possible to determine which method provided by the authors is the most appropriate for the extraction of particular materials. The task is more complicated if it comes to compare the content of polyphenols in different materials as the authors provided TPC in different units and different equivalents, including $\mathrm{mg} / \mathrm{g}, \mu \mathrm{g} / \mathrm{g}, \mathrm{g} / \mathrm{kg}, \mathrm{mg} / \mathrm{ml}, \mu \mathrm{mol} / \mathrm{g}$, weight percentage ( $\mathrm{wt} \%$ ) and gallic acid equivalents, catechins 
equivalent, anthocyanins equivalent and tannic acid, respectively. The most studied was the extraction of grape (seeds, marc, skin, pomace, wastes) and rosemary (leaves).

\section{Future Recommendations}

As it was indicated by a number of publications and reviews, the SFE method did not allow extracting the total content of biologically active phenolic compounds. On the other hand, SFE is not only limited for hydrophilic compounds extraction as a non-polar nature of carbon dioxide may be modified by the addition of polar solvents in order to extract effectively polar groups of compounds. Another aspect is that coupling SFE with other extraction and analytical techniques has gained a lot of interest in recent years. The idea of such techniques makes them a promising tool in the extraction of thermolabile compounds and new directions of researches should be performed towards the optimization of parameters in order to obtain the highest final yield and efficiency. Taking into consideration phenolic compounds extraction with a combined SFE and their importance in various fields, the number of scientific publications is still very sparse.

Author Contributions: K.T. and M.K. Methodology, E.R.; Software, E.R.; Validation, K.T., M.K. and E.R.; Formal Analysis, M.K.; Investigation, K.T.; Resources, K.T. and M.K.; Data Curation, E.R.; Writing-Original Draft Preparation, K.T.; Writing-Review \& Editing, M.K..; Visualization, K.T.; Supervision, E.R.; Project Administration, M.K.; Funding Acquisition, E.R.

Funding: This research received no external funding.

Conflicts of Interest: The authors declare no conflict of interest.

\section{References}

1. De Melo, M.M.R.; Silvestre, A.J.D.; Silva, C.M. Supercritical fluids extraction of vegetable matrices; applications, trends and future perspectives of a convincing green technology. J. Supercrit. Fluids 2017, 92, 115-176. [CrossRef]

2. Manna, L.; Bugnone, C.; Banchero, M. Valorization of hazelnut, coffee and grape wastes through supercritical fluid extraction of triglycerides and polyphenols. J. Supercrit. Fluids 2015, 104, 204-211. [CrossRef]

3. Soobrattee, M.A.; Neergheen, V.S.; Luximan-Ramma, A.; Aruoma, O.J.; Bahorun, T. Phenolics as potential antioxidant therapeutic agents: Mechanism and actions. Mutat. Res. Fund. Mol. 2005, 579, $200-213$. [CrossRef] [PubMed]

4. Adil, I.H.; Cetin, H.I.; Yener, M.E.; Bayindirli, A. Subcritical (carbon dioxide + ethanol) extraction of polyphenols from apple and peach pomaces, and determination of the antioxidant activities of the extracts. J. Supercrit. Fluids 2007, 43, 55-63. [CrossRef]

5. Liu, J.; Lin, S.; Wang, Z.; Wang, C.; Wang, E.; Zhang, Y.; Liu, J. Supercritical fluid extraction of flavonoids from Maydis stigma and its nitrite-scavenging ability. Food Bioprod. Process. 2011, 89, 333-339. [CrossRef]

6. Latoui, M.; Aliakbarian, B.; Casazza, A.A.; Seffen, M.; Converti, A.; Perego, P. Extraction of phenolic compounds from Vitexagnus-castus L. Food Bioprod. Process. 2012, 90, 748-754. [CrossRef]

7. Da Porto, C.; Natolino, A. Supercritical fluids extraction of polyphenols from grape seed (Vitis vinifera): Study on process variables and kinetics. J. Supercrit. Fluids 2017, 130, 239-245. [CrossRef]

8. Monroy, Y.M.; Rodrigues, R.A.F.; Sartoratto, A.; Cabral, F.A. Influence of ethanol, water, and their mixtures as co-solvents of the supercritical carbon dioxide in the extraction of phenolics from purple corn cob (Zea mays L.). J. Supercrit. Fluids 2016, 118, 11-18. [CrossRef]

9. Koubaa, M.; Mhemdi, H.; Fages, J. Recovery of valuable components and inactivating microorganisms in the Agrico-food industry with ultrasound-assisted supercritical fluids technology. J. Supercrit. Fluids 2018, 134, 71-79. [CrossRef]

10. Panja, P. Green extraction methods of food polyphenols from vegetable materials. Curr. Opin. Food Sci. 2017. [CrossRef]

11. Vankar, P.S. Essential oils and frAgricances from natural sources. Resonance 2004, 9, 30-41. [CrossRef]

12. Herrero, M.; Cifuentes, A.; Ibanez, E. Sub- and supercritical fluids extraction of functional ingredients from different natural sources: Plants, food-byproducts, algae and microalgae-A review. Food Chem. 2006, 98, 136-148. [CrossRef] 
13. Farias-Campomanes, A.M.; Rostagno, M.A.; Meireles, M.A.A. Production of polyphenol extracts from grape bagasse using supercritical fluid: Yield, extract composition and economic evaluation. J. Supercrit. Fluids 2013, 77, 70-78. [CrossRef]

14. Mokrani, A.; Madani, K. Effect of solvent, time and temperature on the extraction of phenolic compounds and antioxidant capacity of peach (Prunus persica L.) fruit. Sep. Purif. Technol. 2016, 162, 68-76. [CrossRef]

15. Garcia-Salaz, P.; Moralez-Soto, A.; Segura-Carretero, A.; Fernández-Gutiérrez, A. Phenolic-compound-extraction system for fruit and vegetable samples. Molecules 2010, 15, 8813-8826. [CrossRef] [PubMed]

16. Pereira, D.M.; Valentão, P.; Pereira, J.A.; Andrale, P.B. Phenolics: From chemistry to biology. Molecules 2009, 14, 2202-2211. [CrossRef]

17. Aizpurua-Olaizola, O.; Ormazabal, M.; Vallejo, A.; Olivares, M.; Navarro, P.; Etxebarria, N.; Usobiaga, A. Optimization of supercritical fluids consecutive extractions of fatty acids and polyphenols from Vitis Vinifera grape wastes. J. Food Sci. 2015, 80, 101-107. [CrossRef] [PubMed]

18. Garmus, T.T.; Paviani, L.C.; Queiroga, C.L.; Magalhãea, P.M.; Cabral, F.A. Extraction of phenolic compounds from pitanga (Eugenia uniflora L.) leaves by sequential extraction in fixed bed extractor using supercritical $\mathrm{CO}_{2}$, ethanol and water as solvents. J. Supercrit. Fluids 2018, 86, 4-14. [CrossRef]

19. Bimakr, M.; Rahman, R.A.; Taip, F.S.; Ganjloo, A.; Salleh, L.M.; Selamat, J.; Hamid, A.; Zaidul, I.S.M. Comparison of different extraction methods for the extraction of major bioactive flavonoid compounds from spearmint (Mentha spicata L.) leaves. Food Bioprod. Process. 2011, 89, 67-72. [CrossRef]

20. Paes, J.; Dotta, R.; Barbero, G.F.; Martínez, J. Extraction of phenolic compounds and anthocyanins from blueberry (Vaccinium myrtillus L.) residues using supercritical $\mathrm{CO}_{2}$ and pressurized liquids. J. Supercrit. Fluids 2014, 95, 8-16. [CrossRef]

21. Price, S.F.; Breen, P.J.; Valladao, M.; Watson, B.T. Cluster sun exposure and quercetin in Oinot Noir grapes and wine. Am. J. Enol. Viticult. 1995, 46, 187-194.

22. Pavlić, B.; Bera, O.; Vidović, S.; Ilić, L.; Zerković, Z. Extraction kinetics and ANN simulation of supercritical fluids extraction of sage herbal dust. J. Supercrit. Fluids 2017, 130, 327-336. [CrossRef]

23. Veggi, P.C.; Prado, J.M.; Bataglion, G.A.; Eberlin, M.N.; Meireles, M.A.A. Obtaining phenolic compounds from jatoba (Hymenaea courbaril L.) bark by supercritical fluids extraction. J. Supercrit. Fluids 2014, 89, 68-77. [CrossRef]

24. Pereira, P.; Cebola, M.J.; Oliveira, M.C.; Bernardo-Gil, M.G. Supercritical fluids extraction vs conventional extraction of myrtle leaves and berries: Comparison of antioxidant activity and identification of bioactive compounds. J. Supercrit. Fluids 2016, 113, 1-9. [CrossRef]

25. Rodríquez-Pérez, C.; Mendiola, J.A.; Quirantes-Piné, R.; Ibañez, E.; Segura-Carretero, A. Green downstream processing using supercritical carbon dioxide, $\mathrm{CO}_{2}$-expanded ethanol and pressurized hot water extractions for recovering bioactive compounds from Moringa oleifera leaves. J. Supercrit. Fluids 2016, 116, 90-100. [CrossRef]

26. Abbasi, H.; Rezaei, K.; Emamdjomeh, Z.; Mousavi, S.M.E. Effect of various extraction conditions on the phenolic contents of pomegranate seed oil. Eur. J. Lipid Sci. Technol. 2008, 110, 435-440. [CrossRef]

27. Liu, C.M.; Zhao, J.M.; Li, H.M.; Song, F.R. Supercritical fluids extraction of total flavonoids from leaves of Acanthopanax Senticosus harms. Chem. Res. Chin. Univ. 2007, 23, 233-236. [CrossRef]

28. Bocco, A.; Cuvelier, M.E.; Richard, H.; Berset, C. Antioxidant activity and phenolic composition of citrus peel and seed extracts. J. Agric. Food Chem. 1998, 46, 2123-2129. [CrossRef]

29. He, X.J.; Liu, R.H. Cranberry phytochemicals: Isolation, structure elucidation, and their antiproliferative and antioxidant activities. J. Agric. Food Chem. 2006, 54, 7069. [CrossRef] [PubMed]

30. Laroze, L.E.; Diaz-Reinoso, B.; Moure, A.; Zúñiga, M.E. Extraction of antioxidants from several berries pressing wastes using conventional and supercritical solvents. Eur. Food Res. Technol. 2010, 231, 669-677. [CrossRef]

31. Seabra, I.J.; Braga, M.E.M.; Batista, M.T.; de Sousa, H.C. Effect of solvent $\left(\mathrm{CO}_{2} /\right.$ ethanol $\left./ \mathrm{H}_{2} \mathrm{O}\right)$ on the fractionated enhanced solvent extraction of anthocyanins from elderberry pomace. J. Supercrit. Fluids 2010, 54, 145-152. [CrossRef]

32. Mira, B.; Blasco, M.; Subirats, S. Supercritical $\mathrm{CO}_{2}$ extraction of essential oils from orange peel. J. Supercrit. Fluids 1996, 9, 238-243. [CrossRef] 
33. Babovic, N.; Djilas, S.; Jadranin, M.; Vajs, V.; Ivanovic, J.; Petrovic, S.; Zizovic, I. Supercritical carbon dioxide extraction of antioxidant fractions from selected Lamiaceae herbs and their antioxidant capacity. Innov. Food Sci. Emerg. 2010, 11, 98-107. [CrossRef]

34. Celiktas, O.Y.; Bedir, E.; Sukan, F.V. In vitro antioxidant activities of Rosmarinus officinalis extracts treated with supercritical carbon dioxide. Food Chem. 2007, 101, 1457-1464. [CrossRef]

35. Huang, M.; Ho, C.; Wang, Z.; Ferraro, T.; Lou, Y.; Stauber, K.; Ma, W.; Georgiadis, C.; Laskin, J.; Conney, A. Inhibition of skin tumorgenesis by rosemary and its constituents carnosol and ursolic acid. Cancer Res. 1994, 54, 701-708. [PubMed]

36. Cuvelier, M.; Richard, H.; Berset, C. Antioxidant activity and phenolic composition of pilot-plant and commercial extracts of sage and rosemary. J. Am. Oil Chem. Soc. 1996, 73, 645-652. [CrossRef]

37. Visentín, A.; Cismondi, M.; Maestri, D. Supercritical $\mathrm{CO}_{2}$ fractionation of rosemary ethanolic oleoresins as a method to improve carnosic acid recovery. Innov. Food Sci. Emerg. 2011, 12, 142-145. [CrossRef]

38. Koeppen, B.H.; Basson, D.S. The anthocyanin pigments of Barlinka grapes. Phytochemistry 1996, 5, $183-187$. [CrossRef]

39. Ghaffor, K.; Park, J.; Choi, Y.H. Optimization of supercritical fluids extraction of bioactive compounds from grape (Vitis labrusca B.) peel by using response surface methodology. Innov. Food Sci. Emerg. 2010, 11, 485-490. [CrossRef]

40. Rombaut, N.; Savoire, R.; Thomasset, B.; Bélliard, T.; Castello, J.; Van Hecke, É.; Lanoisellé, J.L. Grape seed oil extraction: Interest of supercritical fluids extraction and gas-assisted mechanical extraction for enhancing polyphenol co-extraction in oil. C. R. Chim. 2014, 17, 284-292. [CrossRef]

41. Marqués, J.L.; Porta, G.D.; Reverchon, E.; Renuncio, J.A.R.; Mainar, A.M. Supercritical antisolvent extraction of antioxidants from grape seeds after vinification. J. Supercrit. Fluids 2013, 82, 238-243. [CrossRef]

42. Ribéreau-Gayon, P.; Glories, Y.; Maujean, A.; Dubourdieu, D. Handbook of Enology the Chemistry of Wine Stabilisation and Treatments; John Wiley \& Sons Ltd.: Chichester, UK, 2006; Volume 2.

43. Wang, H.M.; Pan, J.L.; Chen, C.Y.; Chiu, C.C.; Yang, M.H.; Chang, H.W.; Chang, J.S. Identification of anti-lung cancer extract from Chlorella vulgaris $\mathrm{C}-\mathrm{C}$ by antioxidant property using supercritical carbon dioxide extraction. Process Biochem. 2010, 45, 1865-1872. [CrossRef]

44. Kong, Y.; Fu, Y.J.; Zu, Y.G.; Liu, W.; Wang, W.; Hua, X.; Yang, M. Ethanol modified supercritical fluids extraction and antioxidant activity of cajaninstilbene acid and pinostrobin from pigeonpea Cajanus cajan (L.) Millsp. leaves. Food Chem. 2009, 117, 152-159. [CrossRef]

45. Wu, J.; Luo, J.; Shao, R. Supercritical fluids Extraction of Flavonoids from Dandelion. Adv. J. Food Sci. Technol. 2014, 6, 97-101.

46. Castro-Vargas, H.I.; Rodríguez-Varela, L.I.; Ferreira, S.R.S.; Parada-Alfonso, F. Extraction of phenolic fraction from guava seeds (Psidium guajava L.) using supercritical carbon dioxide and co-solvents. J. Supercrit. Fluids 2010, 51, 319-324. [CrossRef]

47. Liu, X.; Yang, D.L.; Liu, J.J.; Xu, K.; Wu, G.H. Modeling of supercritical fluids extraction of flavonoids from Calycopteris floribunda leaves. Chem. Pap. 2014, 68, 316-323. [CrossRef]

48. Wang, L.; Yang, B.; Du, X.; Yi, C. Optimisation of supercritical fluids extraction of flavonoids from Pueraria lobate. Food Chem. 2008, 108, 737-741. [CrossRef] [PubMed]

49. Liakopoulos, G.; Stavrianakou, S.; Karabourniotis, G. Analysis of epicuticular phenolics of Prunus persica and Olea europaea leaves: Evidence for the chemical origin of the UV-induced blue fluorescence of stomata. Ann. Bot. 2001, 87, 641-648. [CrossRef]

50. Villanueva-Bermejo, D.; Zahran, F.; Troconis, D.; Villalva, M.; Reglero, G.; Fornari, T. Selective precipitation of phenolic compounds from Achillea millefolium L. extracts by supercritical anti-solvent technique. J. Supercrit. Fluids 2017, 120, 52-58. [CrossRef]

51. Kuś, P.; Jerković, I.; Jakovljević, M.; Jokić, S. Extraction of bioactive phenolics from black poplar (Populus nigra L.) buds by supercritical $\mathrm{CO}_{2}$ and its optimization by response surface methodology. J. Pharm. Biomed. Anal. 2018, 152, 128-136. [CrossRef] [PubMed]

52. Babova, O.; Occhipinti, A.; Capuzzo, A.; Maffei, M.E. Extraction of bilberry (Vaccinium myrtillus) antioxidants using supercritical/subcritical $\mathrm{CO}_{2}$ and ethanol as co-solvent. J. Supercrit. Fluids 2016, 107, 358-363. [CrossRef]

53. Rój, E.; Tadić, V.M.; Mišić, D.; Žižović, I.; Arsić, I.; Dobrzyńska-Inger, A.; Kostrzewa, D. Supercritical carbon dioxide hops extracts with antimicrobial properties. Open Chem. 2017, 13, 1157-1171. [CrossRef] 
54. Cardoso, L.C.; Serrano, C.M.; Quintero, E.T.; Lopez, C.P.; Antezana, R.M.; de la Ossa, E.J.M. High pressure extraction of antioxidants from Solanum stenotomun peel. Molecules 2013, 18, 3137-3151. [CrossRef] [PubMed]

55. Ghitescu, R.E.; Volf, I.; Carausu, C.; Bühlmann, A.M.; Gilca, I.A.; Popa, V.I. Optimization of ultrasound-assisted extraction of polyphenols from sprucewood bark. Ultrason. Sonochem. 2015, 22, 535-541. [CrossRef] [PubMed]

56. Kemppainen, K.; Inkinen, J.; Uusitalo, J.; Nakari-Setälä, T.; Siika-aho, M. Hot water extraction and steam explosion as pretreatments for ethanol production from spruce bark. Bioresour. Technol. 2012, 117, 131-139. [CrossRef] [PubMed]

57. Talmaciu, A.I.; Ravber, M.; Volf, I.; Knez, Ž.; Popa, V.I. Isolation of bioactive compounds from spruce bark waste using sub-and supercritical fluid. J. Supercrit. Fluids 2016, 117, 243-251. [CrossRef]

58. Lafka, T.I.; Lazou, A.E.; Sinanoglou, V.J.; Lazos, E.S. Phenolic and antioxidant potential of olive oil mill wastes. Food Chem. 2011, 125, 92-98. [CrossRef]

59. Benelli, P.; Riehl, C.A.S.; Smania Jr., A.; Smania, E.F.A.; Ferreira, S.R.S. Bioactive extracts of orange (Citrus sinensis L. Osbeck) pomace obtained by SFE and low pressure techniques: Mathematical modeling and extract composition. J. Supercrit. Fluids. 2010, 55, 132-141. [CrossRef]

60. He, J.Z.; Shao, P.; Liu, J.H.; Ru, Q.M. Supercritical carbon dioxide extraction of flavonoids from pomelo (Citrus grandis (L.) Osbeck) peel and their antioxidant activity. Int. J. Mol. Sci. 2012, 13, 13065-13078. [CrossRef] [PubMed]

61. Gelmez, N.; Kincal, N.S.; Yener, M.E. Optimization of supercritical carbon dioxide extraction of antioxidants from roasted wheat germ based on yield, total phenolic and tocopherol contents, and antioxidant activities of the extracts. J. Supercrit. Fluids 2009, 48, 217-224. [CrossRef]

62. Kao, T.H.; Lu, Y.F.; Chen, B.H. Preparative chromatography of four groups of isoflavones from soybean cake. Eur. Food Res. Technol. 2005, 221, 459-465. [CrossRef]

63. Fritz, K.L.; Seppanen, C.M.; Kurzer, M.S.; Csallany, A.S. The in vivo antioxidant activity of soybean isoflavones in human subjects. Nutr. Res. 2003, 23, 479-487. [CrossRef]

64. Kao, T.H.; Chien, J.T.; Chen, B.H. Extraction yield of isoflavones from soybean cake as affected by solvent and supercritical carbon dioxide. Food Chem. 2008, 107, 1728-1736. [CrossRef]

65. Zuo, Y.B.; Zheng, A.W.; Yuan, X.G.; Yu, K.T. Extraction of soybean isoflavones from soybean meal with aqueous methanol modified supercritical carbon dioxide. J. Food Eng. 2008, 89, 384-389. [CrossRef]

66. Feliciano, R.P.; Meudt, J.J.; Shanmuganayagam, D.; Metzger, B.T.; Krueger, C.G.; Reed, J.D. Supercritical fluids extraction (SFE) of cranberries does not extract oligomeric proanthocyanidins (PAC) but does alter the chromatography and bioactivity of PAC fractions extracted from SFE residues. J. Agric. Food Chem. 2014, 62, 7730-7737. [CrossRef] [PubMed]

67. Gandhi, K.; Arora, S.; Kumar, A. Industrial applications of supercritical fluids extraction: A review. Int. J. Chem. Stud. 2017, 5, 336-340.

68. Farias-Campomanes, A.M.; Rostagno, M.A.; Coaquira-Quispe, J.J.; Meireles, M.A. Supercritical fluids extraction of polyphenols from lees: Overall extraction curve, kinetic data and composition of the extracts. Bioresour. Bioprocess. 2015, 2. [CrossRef]

69. Piantino, C.R.; Aquino, F.W.B.; Follegatti-Romero, L.A.; Cabral, F.A. Supercritical $\mathrm{CO}_{2}$ extraction of phenolic compounds from Baccharis dracunculifolia. J. Supercrit. Fluids 2008, 47, 209-214. [CrossRef]

70. Reátegui, J.L.P.; de Fonesca Machado, A.P.; Barbero, G.F.; Rezende, C.A.; Martínez, J. Extraction of antioxidant compounds from blackberry (Rubus sp..) bagasse using supercritical $\mathrm{CO}_{2}$ assisted by ultrasound. J. Supercrit. Fluids 2014, 94, 223-233. [CrossRef]

71. Sodeifian, G.; Ardestani, N.S.; Sajadian, S.A.; Moghadamian, K. Properties of Portulaca oleracea seed oil via supercritical fluids extraction: Experimental and optimization. J. Supercrit. Fluids 2018, 135, 34-44. [CrossRef]

72. Haghayegh, M.; Zabihi, F.; Eikani, M.H.; Moghadas, B.K.; Yazdi, S.A.V. Supercritical fluids extraction of flavonoids and terpenoids from herbal compounds: Experiments and mathematical modeling. J. Essent. Oil Bear. Plants 2015, 18, 1253-1265. [CrossRef]

73. Espinosa-Pardo, F.A.; Martinez, J.; Martinez-Correa, H.A. Extraction of bioactive compounds from peach palm pulp (Bactris gasipaes) using supercritical $\mathrm{CO}_{2}$. J. Supercrit. Fluids 2014, 93, 2-6. [CrossRef]

74. Chatterjee, D.; Bhattacharjee, P. Supercritical carbon dioxide extraction of antioxidant rich fraction from Phormidium valderianum: Optimization of experimental process parameters. Algal Res. 2014, 3, 49-54. [CrossRef] 
75. Senorans, F.J.; Ibanez, E.; Cavero, S.; Tabera, J.; Reglero, G. Liquid chromatographic-mass spectrometric analysis of supercritical-fluids extract of rosemary plants. J. Chromatogr. A 2000, 870, 491-499. [CrossRef]

76. Carvalho, R.N., Jr.; Moura, L.S.; Rosa, P.T.V.; Meireles, M.A.A. Supercritical fluids extraction from rosemary (Rosmarinus officinalis): Kinetic data, extract's global yield, composition, and antioxidant activity. J. Supercrit. Fluids 2005, 35, 197-204. [CrossRef]

77. Liza, M.S.; Rahman, R.A.; Mandana, B.; Jinap, S.; Rahmat, A.; Zaidul, I.S.M.; Hamid, A. Supercritical carbon dioxide extraction of bioactive flavonoid from Strobilanthes crispus (Pecah Kaca). Food Bioprod. Process. 2010, 88, 319-326. [CrossRef]

78. Zhang, Y.; Li, S.; Wu, X.; Zhao, X. Macroporous resin adsorption for purification of flavonoids in Houttuynia cordatu Thunb. Chin. J. Chem. Eng. 2007, 15, 872-876. [CrossRef]

79. Wu, J.J.; Lin, J.C.; Wang, C.H.; Jong, T.T.; Yang, H.L.; Hsu, S.L.; Chang, C.M.J. Extraction of antioxidative compounds from wine lees using supercritical fluid and associated anti-tyrosinase activity. J. Supercrit. Fluids 2009, 50, 33-41. [CrossRef]

80. Ivanović, J.; Dilas, S.; Jadranin, M.; Vajs, V.; Babović, N.; Petrović, S.; Žižović, I. Supercritical carbon dioxide extraction of antioxidants from rosemary (Rosmarinus officinalis L.) and sage (Salvia officinalis L.). J. Serb. Chem. Soc. 2009, 74, 717-732. [CrossRef]

81. Cavalcanti, R.N.; Navarro-Diaz, H.J.; Santos, D.T.; Rostagno, M.A.; Meireles, M.A.A. Supercritical carbon dioxide extraction of polyphenols from pomegranate (Punica granatum L.) leaves: Chemical composition, economic evaluation and chemometric Approach. J. Food Res. 2012, 1, 282-294. [CrossRef]

82. Prado, I.M.; Prado, G.H.C.; Prado, J.M.; Meireles, A.A. Supercritical $\mathrm{CO}_{2}$ and low-pressure solvent extraction of mango (Mangifera indica) leaves: Global yield, extraction kinetics, chemical composition and cost of manufacturing. Food Bioprod. Process. 2013, 91, 656-664. [CrossRef]

83. Arlorio, M.; Goisson, J.D.; Travaglia, F.; Varsaldi, F.; Miglio, G.; Lombardi, G.; Martelli, A. Antioxidant and biological activity of phenolic pigments from Theobroma cacao hulls extracted with supercritical $\mathrm{CO}_{2}$. Food Res. Int. 2005, 38, 1009-1014. [CrossRef]

84. Nguyen, U.; Frakman, G.; Evans, D.A. Process for extracting antioxidants from Labiatae herbs. U.S. Patent 5017,397, 21 May 1991.

85. Visentin, A.; Rodríguez-Rojo, S.; Navarrete, A.; Maestri, D.; Cocero, M.J. Precipitation and encapsulation of rosemary antioxidants by supercritical antisolvent process. J. Food Eng. 2012, 109, 9-15. [CrossRef]

86. Roh, M.K.; Uddin, M.S.; Chun, B.S. Extraction of fucoxanthin and polyphenol from Undaria pinnatifida using supercritical carbon dioxide with co-solvent. Biotechnol. Bioproc. Eng. 2008, 13, 724-729. [CrossRef]

87. Walters, M.; Ribeiro, A.P.L.; Hosseinian, F.; Tsopmo, A. Phenolic acids, avenanthramides, and antioxidant activity of oats defatted with hexane or supercritical fluids. J. Cereal Sci. 2018, 79, 21-26. [CrossRef]

88. Kryževičiute, N.; Kraujalis, P.; Venskutonis, P.R. Optimization of high pressure extraction processes for the separation of raspberry pomace into lipophilic and hydrophilic fractions. J. Supercrit. Fluids 2016, 108, 61-68. [CrossRef]

89. Povilaitis, D.; Venskutonis, P.R. Optimization of supercritical carbon dioxide extraction of rye bran using response surface methodology and evaluation of extract properties. J. Supercrit. Fluids 2015, 100, 194-200. [CrossRef]

90. Cavero, S.; Jaime, L.; Martin-Alvarez, P.J.; Senorans, F.J.; Reglero, G.; Ibanez, E. In vitro antioxidant analysis of supercritical Fluids extracts from rosemary (Rosmarinus officinalis L.). Eur. Food Res. Technol. 2005, 221, 478-486. [CrossRef]

91. Leitao, N.C.M.C.S.; Prado, G.H.C.; Veggi, P.C.; Meireles, M.A.A.; Pereira, C.G. Anacardium occidentale L. leaves extraction via SFE: Global yields, extraction kinetics, mathematical modeling and economic evaluation. J. Supercrit. Fluids 2013, 78, 114-123. [CrossRef]

92. De Azevedo, A.B.A.; Mazzafera, P.; Mohamed, R.S.; de Melo, S.A.B.; Kieckbusch, T.G. Extraction of caffeine, chlorogenic acids and lipids from green coffee beans using supercritical carbon dioxide and co-solvents. Braz. J. Chem. Eng. 2008, 825, 543-552. [CrossRef]

93. Chang, C.J.; Chiu, K.L.; Chen, Y.L.; Chang, C.Y. Separation of catechins from green tea using carbon dioxide extraction. Food Chem. 2000, 68, 109-113. [CrossRef]

94. Pereira, P.; Bernardo-Gil, M.G.; Cebola, M.J.; Mauricio, E.; Romano, A. Supercritical fluids extracts with antioxidant and antimicrobial activities from myrtle (Myrtus communis L.) leaves. Response surface optimization. J. Supercrit. Fluids 2013, 83, 57-64. [CrossRef] 
95. Louli, V.; Ragoussis, N.; Magoulas, K. Recovery of phenolic antioxidants from wine industry by-products. Bioresour. Technol. 2007, 92, 201-208. [CrossRef]

96. Pavlić, B.; Bera, O.; Teslić, N.; Vidović, S.; Parpinello, G.; Zerković, Z. Chemical profile and antioxidant activity of sage dust extracts obtained by supercritical fluids extraction. Ind. Crop. Prod. 2018, 120, 305-312. [CrossRef]

97. López-Padilla, A.; Ruiz-Rodriguez, A.; Flórez, C.E.R.; Barrios, B.M.R.; Reglero, C.; Fornari, T. Vaccinium meridionale Swartz supercritical $\mathrm{CO}_{2}$ extraction: Effect of process conditions and scaling up. Materials 2016, 5, 519. [CrossRef] [PubMed]

98. De Cássia Rodrigues Batista, C.; de Oliveira, M.S.; Araújo, M.E.; Rodrigues, A.M.C.; Botelho, J.R.S.; da Silva Souza Filho, A.P.; Machado, N.T.; Carvalho, R.N. Supercritical $\mathrm{CO}_{2}$ extraction of açaí (Euterpe oleracea) berry oil: Global yield, fatty acids, allelopathic activities, and determination of phenolic and anthocyanins total compounds in the residual pulp. J. Supercrit. Fluids 2016, 107, 364-369. [CrossRef]

99. Natolino, A.; da Porto, C.; Rodríguez-Rojo, S.; Moreno, T.; Cocero, M.J. Supercritical antisolvent precipitation of polyphenols from grape marc extract. J. Supercrit. Fluids 2016, 118, 54-63. [CrossRef]

100. Bermejo, D.V.; Ibanez, E.; Reglero, G.; Turner, C.; Fornari, T.; Rodriquez-Meizoso, I. High catechins/low caffeine powder from green tea leaves by pressurized liquid extraction and supercritical antisolvent precipitation. Sep. Purif. Technol. 2015, 148, 49-56. [CrossRef]

101. Ekart, M.P.; Bennett, K.L.; Ekart, S.M.; Gurdial, G.S.; Liotta, C.L.; Eckert, C.A. Cosolvent interactions in supercritical fluids solutions. AIChE 1992, 39, 235-348. [CrossRef]

102. Paula, J.T.; Paviani, L.C.; Foglio, M.A.; Sousa, I.M.O.; Cabral, F.A. Extraction of anthocyanins from Arrabidaea chica in fixed bed using $\mathrm{CO}_{2}$ and $\mathrm{CO}_{2}$ /ethanol/water mixtures as solvents. J. Supercrit. Fluids 2013, 81, $33-41$. [CrossRef]

103. Paula, J.T.; Paviani, L.C.; Foglio, M.A.; Sousa, I.M.O.; Duarte, G.H.B.; Jorge, M.P.; Eberlin, M.N.; Cabral, F.A. Extraction of anthocyanins and luteolin from Arrabidaea chica by sequential extraction in fixed bed using supercritical $\mathrm{CO}_{2}$, ethanol and water as solvents. J. Supercrit. Fluids 2014, 86, 100-107. [CrossRef]

104. Zulkafli, Z.D.; Wang, H.; Miyashita, F.; Utsumi, N.; Tamura, K. Cosolvent-modified supercritical carbon dioxide extraction of phenolic compounds from bamboo leaves (Sasa palmata). J. Supercrit. Fluids 2014, 94, 123-129. [CrossRef]

105. Kerbstadt, S.; Eliasson, L.; Mustafa, A.; Ahrne, L. Effect of novel drying techniques on the extraction of anthocyanins from bilberry press cake using supercritical carbon dioxide. Innov. Food Sci. Emerg. 2015, 29, 209-214. [CrossRef]

106. Maran, J.P.; Priya, B.; Manikandan, S. Modeling and optimization of supercritical fluids extraction of anthocyanin and phenolic compounds from Syzygium cumini fruit pulp. J. Food Sci. Technol. 2014, 51, 1938-1946. [CrossRef] [PubMed]

107. Wang, B.J.; Liu, C.T.; Tseng, C.Y.; Yu, Z.R. Antioxidant activity of Bupleurum kaoi Liu (Chao et Chuang) fractions fractionated by supercritical $\mathrm{CO}_{2}$. LWT 2005, 38, 281-287. [CrossRef]

108. Da Porto, C.; Natolino, A.; Decorti, D. The combined extraction of polyphenols from grape marc: Ultrasound assisted extraction followed by supercritical $\mathrm{CO}_{2}$ extraction of ultrasound-raffinate. LWT-Food Sci. Technol. 2015, 61, 98-104. [CrossRef]

109. Woźniak, Ł.; Marszałek, K.; Skapska, S.; Jędrzejczak, R. The application of supercritical carbon dioxide and ethanol for the extraction of phenolic compounds from choke pomace. Appl. Sci. 2017, 7, 322. [CrossRef]

110. Giannuzzo, A.N.; Boggetti, H.J.; Nazareno, M.A.; Mishima, H.T. Supercritical fluids extraction of naringin from the peel of Citrus paradise. Phytochem. Anal. 2003, 14, 221-223. [CrossRef] [PubMed]

111. Vatai, T.; Škerget, M.; Knez, Ž. Extraction of phenolic compounds from elder berry and different grape marc varieties using organic solvents and/or supercritical carbon dioxide. J. Food Eng. 2009, 90, $246-254$. [CrossRef]

112. Santos, S.A.O.; Villaverde, J.J.; Silva, C.M.; Neto, C.P.; Silvestre, A.J.D. Supercritical fluids extraction of phenolic compounds from Eucalyptus globulus Labill bark. J. Supercrit. Fluids 2012, 71, 71-79. [CrossRef]

113. Chinnarasua, C.; Montes, A.; Fernandez-Ponce, M.T.; Casas, L.; Mantell, C.; Pereyra, C.; Martinez de la Ossa, E.J.; Pattabhi, S. Natural antioxidant fine particles recovery from Eucalyptus globulus leaves using supercritical carbon dioxide assisted processes. J. Supercrit. Fluids 2015, 101, 161-169. [CrossRef]

114. Chiu, K.L.; Cheng, Y.C.; Chen, J.H.; Chang, C.J.; Yang, P.W. Supercritical fluid extraction of Ginkgo ginkgolides and flavonoids. J. Supercrit. Fluids 2002, 24, 77-87. [CrossRef] 
115. Palma, M.; Taylor, L.T. Extraction of polyphenolic compounds from grape seeds with near critical carbon dioxide. J. Chromatogr. A 1999, 849, 117-124. [CrossRef]

116. Murga, R.; Rutz, R.; Beltran, A.; Cabezas, J.L. Extraction of natural complex phenols and tannins from grape seeds by using supercritical mixtures of carbon dioxide and alcohol. J. Agric. Food Chem. 2000, 48, 3408-3412. [CrossRef] [PubMed]

117. Khorassani, M.A.; Taylor, L.T. Sequential fractionation of grape seeds into oils, polyphenols, and procyanidins via a single system employing $\mathrm{CO}_{2}$-based fluid. J. Agric. Food Chem. 2004, 52, 2440-2444. [CrossRef] [PubMed]

118. Ghafoor, K.; Al-Juhaimi, F.Y.; Choi, Y.H. Supercritical fluids extraction of phenolic compounds and antioxidants from (Vitis labrusca B.) seeds. Plant Foods Hum. Nut. 2012, 67, 407-414. [CrossRef] [PubMed]

119. Da Porto, C.; Natolino, A.; Decorti, D. Extraction of proanthocyanidins from grape marc by supercritical fluids extraction using $\mathrm{CO}_{2}$ as solvent and ethanol-water mixture as co-solvent. J. Supercrit. Fluids 2014, 87, 59-64. [CrossRef]

120. Da Porto, C.; Decorti, D.; Natolino, A. Water and ethanol as co-solvent in supercritical Fluids extraction of proanthocyanidins from grape marc: A comparison and a proposal. J. Supercrit. Fluids 2014, 87, 1-8. [CrossRef]

121. Pascaul-Marti, M.C.; Salvador, A.; Chafer, A.; Berna, A. Supercritical fluids extraction of resveratrol from grape skin of Vitis vinifera and determination by HPLC. Talanta 2001, 54, 735-740. [CrossRef]

122. Bleve, M.; Ciurlia, L.; Erroi, E.; Lionetto, G.; Longo, L.; Rescio, L.; Schettino, T.; Vasapollo, G. An innovative method for the purification of anthocyanins from grape skin extracts by using liquid and sub-critical carbon dioxide. Sep. Purific. Technol. 2008, 64, 192-197. [CrossRef]

123. Pinelo, M.; Ruiz-Rodrigez, A.; Sineiro, J.; Senorans, F.J.; Reglero, G.; Nunez, M.J. Supercritical fluids and solid-liquid extraction of phenolic antioxidants from grape pomace: A comparative study. Eur. Food Res. Technol. 2007, 226, 199-205. [CrossRef]

124. Casas, L.; Mantell, C.; Rodríguez, M.; Martínez de la Ossa, E.J.; Roldán, A.; De Ory, I.; Caro, I.; Blandino, A. Extraction of resveratrol from the pomace of Palomino fino grapes by supercritical carbon dioxide. J. Food Eng. 2010, 96, 304-308. [CrossRef]

125. Fiori, L.; de Faveri, D.; Casazza, A.A.; Perego, P. Grape by-products: Extraction of polyphenolic compounds using supercritical $\mathrm{CO}_{2}$ and liquid organic solvent-A preliminary investigation. CyTA J. Food 2009, 7, 163-171. [CrossRef]

126. Fabrowska, J.; Ibañez, E.; Łęska, B.; Herrero, M. Supercritical fluids extraction as a tool to valorize underexploited freshwater green algae. Algae Res. 2016, 19, 237-245. [CrossRef]

127. Machado, B.A.S.; de Abreu Barreto, G.; Costa, A.S.; Costa, S.S.; Silva, R.P.D.; de Silva, D.F.; Brandao, H.N.; de Rocha, J.L.C.; Nunes, S.B.; Umsza-Guez, M.A.; et al. Determination of parameters for the supercritical extraction of antioxidant compounds from green propolis using carbon dioxide and ethanol as co-solvent. PLoS ONE 2015. [CrossRef] [PubMed]

128. Huang, K.J.; Wu, J.J.; Chiu, Y.H.; Lai, C.Y.; Chang, C.M. Designed polar cosolvent-modified supercritical $\mathrm{CO}_{2}$ removing caffeine from and retaining catechins in green tea powder using response surface methodology. J. Agric. Food Chem. 2007, 55, 9014-9020. [CrossRef] [PubMed]

129. Bermejo, D.V.; Ibanez, E.; Reglero, G.; Fornari, T. Effect of cosolvents (ethyl lactate, ethyl acetate and ethanol) on the supercritical $\mathrm{CO}_{2}$ extraction of caffeine from green tea. J. Supercrit. Fluids 2015, 107, 507-512. [CrossRef]

130. He, G.Q.; Xiong, H.P.; Chen, Q.H.; Ruan, H.; Wang, Z.Y.; Traore, L. Optimization of conditions for supercritical fluids extraction of flavonoids from hops (Humulus lupulus L.). J. Zhenjiang Univ. Sci. B 2005, 6, 999-1004. [CrossRef] [PubMed]

131. Del Pilar Garcia-Mendoza, M.; Espinosa-Pardo, F.A.; Fernandez, A.M.B.G.; Marostica, B.M.R.; Ariel, J.M.; Martinez, R.J. Extraction of phenolic compounds and anthocyanins from jucara (Euterpe edulis Mart.) residues using pressurized liquids and supercritical fluid. J. Supercrit. Fluids 2016, 119, 9-16. [CrossRef]

132. Liu, C.M.; Zhao, X.L.; Liu, Z.Q.; Xing, J.P. Isolation and extraction of total flavonoids from Epimedium Koreanum Nakai by supercritical fluids extraction. Chem. Res. Chin. Univ. 2004, 20, 707-710.

133. Bitencourt, R.G.; Queiroga, C.L.; Duarte, G.H.B.; Eberlin, M.N.; Kohn, L.K.; Arns, C.W.; Cabral, F.A. Sequential extraction of bioactive compounds from Melia azedarach L. in fixed bed extractor using $\mathrm{CO}_{2}$, ethanol and water. J. Supercrit. Fluids 2014, 95, 355-363. [CrossRef] 
134. Shan, B.; Xie, J.H.; Zhu, J.H.; Peng, Y. Ethanol modified supercritical carbon dioxide extraction of flavonoids from Momordica charantia L. and its antioxidant activity. Food Bioprod. Process. 2012, 90, 579-587. [CrossRef]

135. Ouédraogo, J.C.W.; Dicko, C.; Kini, F.B.; Bonzi-Coulibaly, Y.L.; Szwajcer Dey, E. Enhanced extraction of flavonoids from Odontonema strictum leaves with antioxidant activity using supercritical carbon dioxide fluids combined with ethanol. J. Supercrit. Fluids 2018, 131, 66-71. [CrossRef]

136. Escobedo-Flores, Y.; Chavez-Flores, D.; Salmeron, I.; Molina-Guerrero, C.; Perez-Vega, S. Optimization of supercritical fluids extraction of polyphenols from oats (Avena sativa L.) and their antioxidant activities. J. Cereal Sci. 2018, 80, 198-204. [CrossRef]

137. Le Floch, F.; Tena, M.T.; Rios, A.; Valárcel, M. Supercritical fluids extraction of phenol compounds from olive leaves. Talanta 1998, 46, 1123-1130. [CrossRef]

138. Peng, J.; Fan, G.; Chai, Y.; Wu, Y. Efficient new method for extraction and isolation of three flavonoids from Patrinia villosa Juss. by supercritical fluids extraction and high-speed counter-current chromatography. J. Chromatogr. A 2006, 1102, 44-50. [CrossRef] [PubMed]

139. Kazan, A.; Koyu, H.; Turu, I.C.; Yesil-Celiktas, O. Supercritical fluids extraction of Prunus persica leaves and utilization possibilities as a source of phenolic compounds. J. Supercrit. Fluids 2014, 92, 55-59. [CrossRef]

140. Goli, A.H.; Barzegar, M.; Sahari, M.A. Antioxidant activity and total phenolic compounds of pistachio (Pistachia vera) hull extracts. Food Chem. 2005, 92, 521-525. [CrossRef]

141. Monroy, Y.M.; Rodriques, R.A.F.; Sartoratto, A.; Cabral, F.A. Extraction of bioactive compounds from cob and pericarp of purple corn (Zea mays L.) by sequential extraction in fixed bed extractor using supercritical $\mathrm{CO}_{2}$, ethanol, and water as solvents. J. Supercrit. Fluids 2016, 107, 250-259. [CrossRef]

142. Monroy, Y.M.; Rodrigues, R.A.F.; Sartoratto, A.; Cabral, F.A. Optimization of the extraction of phenolic compounds from purple corn cob (Zea mays L.) by sequential extraction using supercritical carbon dioxide, ethanol and water as solvents. J. Supercrit. Fluids 2016, 116, 10-19. [CrossRef]

143. Del Pilar Sánchez-Camargo, A.; Valdés, A.; Sullini, G.; Garcia-Cañas, V.; Cifuentes, A.; Ibáñez, E.; Herrero, M. Two-step sequential supercritical Fluids extracts from rosemary with enhanced anti-proliferative activity. J. Funct. Food 2014, 11, 293-303. [CrossRef]

144. Lin, M.C.; Tsai, M.J.; Wen, K.C. Supercritical fluids extraction of flavonoids from Scutellariae Radic. J. Chromatogr. A 1999, 830, 387-395. [CrossRef]

145. Alvarez, M.V.; Cabred, S.; Ramirez, C.L.; Fanovich, M.A. Valorization on an Agricoindustrial soybean residue by supercritical fluids extraction of phytochemical compounds. J. Supercrit. Fluids 2019, 143, 90-96. [CrossRef]

146. Leal, P.F.; Maia, N.B.; Carmello, Q.A.C.; Catharino, R.R.; Eberlin, M.N.; Meireles, A.A. Sweet basil (Ocimum basilicum) extracts obtained by supercritical fluids extraction (SFE): Global yields, chemical composition, antioxidant activity, and estimation of the cost of manufacturing. Food Bioprocess. Tech. 2008, 1, 326-338. [CrossRef]

147. Li, B.; Xu, Y.; Jin, Y.X.; Wu, Y.Y.; Tu, Y.Y. Response surface optimization of supercritical fluids extraction of kaempferol glycosides from tea seed cake. Ind. Crop. Prod. 2010, 32, 123-128. [CrossRef]

148. Valadez-Carmona, L.; Ortiz-Moreno, A.; Ceballos-Reyes, G.; Mendiola, J.A.; Ibáñez, E. Valorization of cacao pod husk through supercritical fluids extraction of phenolic compounds. J. Supercrit. Fluids 2018, 131, 99-105. [CrossRef]

149. Zachova, Z.; Třiska, J.; Vrchotová, N.; Balík, J.; Sajfrtová, M.; Sovová, H. Combining high-pressure methods for extraction of stilbenes from grape cane. J. Supercrit. Fluids 2018. [CrossRef]

150. Roseiro, L.B.; Duarte, L.C.; Oliveira, D.L.; Roque, R.; Bernardo-Gil, M.G.; Martins, A.I.; Sepúlveda, C.; Almeida, J.; Meireles, M.; Gírio, F.M.; et al. Supercritical, ultrasound and conventional extracts from carob (Ceratonia siliqua L.) biomass: Effect on the phenolic profile and antiproliferative activity. Ind. Crop. Prod. 2013, 47, 132-138. [CrossRef]

151. Stevenson, D.G.; Inglett, G.E.; Chen, D.; Biswas, A.; Eller, F.J.; Evangelista, R.L. Phenolic content and antioxidant capacity of supercritical carbon dioxide-treated and air-classified oat bran concentrate microwave-irradiated in water or ethanol at varying temperatures. Food Chem. 2008, 108, 23-30. [CrossRef]

152. Rostagno, M.A.; Prado, J.M. Natural Product Extraction: Principles and Applications; RSC Publishing: Londres, UK, 2013; pp. 89-112. 
153. Liu, J.; Ji, F.; Chen, F.; Guo, W.; Yang, M.; Huang, S.; Zhang, F.; Liu, Y. Determination of garlic phenolic compounds using supercritical fluids extraction coupled to supercritical fluids chromatography/tandem mass spectrometry. J. Pharm. Biomed. Anal. 2018, 159, 513-523. [CrossRef] [PubMed]

154. Johansen, H.R.; Becher, G.; Greibrokk, T. Determination of planar PCBs by combining on-line SFE-HPLC and GC-ECD or GC/MS. Anal. Chem. 1994, 66, 4068-4073. [CrossRef] [PubMed]

155. Hawthorne, S.B.; Miller, D.J.; Krieger, M.S. Coupled SFE-GC: A rapid and simple technique for extracting, identifying, and quantitating organic analytes from solids and sorbent resins. J. Chromatogr. Sci. 1989, 27, 347-354. [CrossRef]

156. Amador-Hernández, J.; De Castro, M.D.L. On-line detection for supercritical-fluids extraction. J. Biochem. Biophys. Methods 2000, 43, 329-343. [CrossRef]

157. Naeeni, M.H.; Yamini, Y.; Rezaee, M. Combination of supercritical fluids extraction with dispersive liquid-liquid microextraction for extraction of organophosphorus pesticides from soil and marine sediment samples. J. Supercrit. Fluids 2011, 57, 219-226. [CrossRef]

158. Hofstetter, R.; Fassauer, G.M.; Link, A. Supercritical fluids extraction (SFE) of ketamine metabolites from dried urine and on-line quantification by supercritical fluids chromatography and single mass detection (on-line SFE-SFC-MS). J. Chromatogr. B 2018, 1076, 77-83. [CrossRef] [PubMed]

159. Chemat, F.; Vian, M.A.; Cravotto, G. Green extraction of natural products: Concept and principles. Int. J. Mol. Sci. 2012, 13, 8615-8627. [CrossRef] [PubMed]

160. Ameer, K.; Shahbaz, H.M.; Kwon, J.H. Green extraction methods for polyphenols from plant matrices and their byproducts: A review. Compr. Rev. Food Sci. Food Saf. 2017, 16, 295-315. [CrossRef]

161. Khoddami, A.; Wilkes, M.A.; Roberts, T.H. Techniques for analysis of plant phenolic compounds. Molecules 2013, 18, 2328-2375. [CrossRef] [PubMed]

162. Rodríguez-Solana, R.; Salgado, J.M.; Domínguez, J.M.; Cortés-Diéguez, S. Comparison of soxhlet, accelerated solvent and supercritical fluids extraction techniques for volatile (GC-MS and GC/FID) and phenolic compounds (HPLC-ESI/MS/MS) from Lamiaceae species. Phytochem. Anal. 2015, 26, 61-71. [CrossRef] [PubMed]

163. Llompart, M.P.; Lorenzo, R.A.; Cela, R.; Li, K.; Bélanger, M.R.; Paré, J.R.J. Evaluation of supercritical fluids extraction, microwave-assisted extraction and sonication in the determination of some phenolic compounds from various soil matrices. J. Chromatogr. A 1997, 774, 243-251. [CrossRef]

164. Dias, A.L.B.; Sergio, C.S.A.; Santos, P.; Barbero, G.F.; Rezende, C.A.; Martínez, J. Effect of ultrasound on the supercritical $\mathrm{CO}_{2}$ extraction of bioactive compounds from dedo de moça pepper (Capsicum baccatum $\mathrm{L}$. var. pendulum). Ultrason. Sonochem. 2016, 31, 284-294. [CrossRef] [PubMed]

165. Anaëlle, T.; Loen, E.S.; Laurent, V.; Elena, I.; Mendiola, J.A.; Stéphane, C.; Nelly, K.; Stéphane, L.B.; Luc, M.; Valérie, S.P. Green improved processes to extract bioactive phenolic compounds from brown macroalgae using Sargassum muticum as model. Talanta 2013, 104, 44-52. [CrossRef] [PubMed]

166. Kraujaliene, V.; Pukalskas, A.; Venskutonis, P.R. Biorefining of goldenrod (Solidago virgaurea L.) leaves by supercritical fluids and pressurized liquid extraction and evaluation of antioxidant properties and main phytochemicals in the fractions and plant material. J. Funct. Foods 2017, 37, 200-208. [CrossRef]

167. Fernández-Ponce, M.; Parjikolaei, B.R.; Lari, H.N.; Casas, L.; Mantell, C.; Martínez de la Ossa, E.J. Pilot-plant scale extraction of phenolic compounds from mango leaves using different green techniques: Kinetic and scale up study. Chem. Eng. 2016, 299, 420-430. [CrossRef]

168. Taamalli, A.; Arráez-Román, D.; Barrajón-Catalán, E.; Ruiz-Torres, V.; Pérez-Sánchez, A.; Herrero, M.; Ibaňez, E.; Micol, V.; Zarrouk, M.; Segura-Carretero, A.; et al. Use of advanced techniques for the extraction of phenolic compounds from Tunisian olive leaves: Phenolic composition and cytotoxicity against human breast cancer cells. Food. Chem. Toxicol. 2012, 50, 1817-1825. [CrossRef] [PubMed]

(C) 2018 by the authors. Licensee MDPI, Basel, Switzerland. This article is an open access article distributed under the terms and conditions of the Creative Commons Attribution (CC BY) license (http://creativecommons.org/licenses/by/4.0/). 